\title{
Investigating the Effects of Consumer Innovativeness, Service Quality and Service Switching Costs on Service Loyalty in the Mobile Phone Service Context
}

\author{
Farzana Quoquab, ${ }^{1}$ Nor Liza Abdullah, ${ }^{2}$ and Jihad Mohammad ${ }^{1 *}$ \\ ${ }^{1}$ International Business School, Universiti Teknologi Malaysia. \\ ${ }^{2}$ Faculty of Economics and Management,Universiti Kebangsaan Malaysia.
}

\begin{abstract}
The objective of this study is to examine the effects of consumer innovativeness, service quality, service switching costs and service satisfaction on service loyalty among mobile phone service users. A cross sectional survey was employed which yielded 535 responses. Structural equation modelling using the AMOS version 2.0 was utilized to test study the hypotheses. Test results reveal that service satisfaction, service switching costs and service quality are the three antecedents that directly influence service loyalty. How ever, consumer innovativeness does not have any direct effect on service loyalty. Moreover, service satisfaction is found to be a partial mediator between 'service quality' and 'service loyalty'. Findings from this study will develop insights to enable policy-makers, managers and marketers to better strategize and effectively implement loyalty programs and prevent their customers from switching. This will enhance value creation for both their users and for the industry.
\end{abstract}

Abstrak: Tujuan penelitian ini adalah untuk menguji efek keinovatifan konsumen, kualitas layanan, biaya peralihan layanan dan kepuasan layanan pada loyalitas layanan di kalangan pengguna layanan telepon seluler. Survei cross sectional yang dilakukan mendapatkan 535 tanggapan. Pemodelan persamaan struktural menggunakan AMOS versi 2.0 digunakan untuk menguji hipotesis. Hasil pengujian mengungkapkan bahwa kepuasan layanan, biaya peralihan layanan dan kualitas layanan adalah tiga anteseden yang secara langsung mempengaruhi loyalitas layanan. Namun, keinovatifan konsumen tidak memiliki efek langsung pada loyalitas layanan. Lebih lanjut, kepuasan layanan ditemukan sebagai pemediasi parsial antara 'kualitas layanan' dan 'loyalitas layanan'. Temuan studi ini akan mengembangkan pilihan yang memungkinkan para pembuat kebijakan, manajer dan pemasar untuk merancang strategi yang lebih baik dan secara efektif mengimplementasikan program loyalitas dan mencegah pelanggan mereka beralih. Hal ini akan meningkatkan penciptaan nilai bagi para pengguna dan bagi industri.

Keywords: consumer innovativeness; mobile phone service users; service quality; service satisfaction; service switching cost; service loyalty

JEL classification: $\mathrm{M} 31$

* Corresponding author's e-mail: jihad@ibs.utm.my 


\section{Introduction}

Achieving the loyalty of their customers has become the main concern for service industry managers, since it contributes significantly to their firms' profitability (Reichheld 2002; Reichheld and Sasser 1990; Rust and Zahorik 1993), survival and growth (Reichheld 1996), and for providing new referrals for their firms through positive word of mouth endorsements (Ganesh et al. 2000; Gremler and Brown 1996). However, retaining current customers and precluding them from switching is a very difficult task, due to the availability of alternative service providers (Habib et al. 2011; Quoquab et al. 2014; Tuu and Olsen 2013). This is more crucial for the telecoms' service industry (Adham and Said 2010; Said and Adham 2010; Narayana 2011). When consumers switch from their existing service provider, many established relationships with that service provider are likely to deteriorate and dissolve (Al-kwifi et al. 2014; Annala et al. 2013; Gustafsson et al. 2005). As a consequence, dissatisfied switchers can generate negative word of mouth reviews that can damage a firm's reputation and brand image (Lopez et al. 2006). In addition, the firm needs to spend money to attract new consumers through advertising and offering promotional or initial discounts (Lopez et al. 2006). In fact, some business analysts have indicated that the costs of gaining new consumers are five times more expensive than those of maintaining the current consumers (Keiningham et al. 2005; Mittal and Lasser 1998). Hence, the effort to retain current consumers is much more worthwhile than searching for new ones (Liu et al. 2014). Due to these serious problems, researchers and practitioners are very concerned about understanding the issues that relate to keeping consumers loyal and reducing the switching rate in their industries.
Past research has studied 'consumer innovativeness' in relation to variables such as: (i) perceived risk (Hir unyawipad and Paswan 2006), (ii) product interest (Robertson 1968), (iii) self-congruence (Cowart et al. 2008), (iv) consumers personality traits (Donnelly and Ivancevich 1974), (v) product involvement (Wang et al. 2006), and (vi) purchase and consumption characteristics (Taylor 1977). However, none of these studies examined the influence of consumer innovativeness on loyalty or switching behaviour. For the present study consumer innovativeness is considered as the user's intrinsic motivation to explore another service provider's network and/or to switch to an upgraded package (such as a SMART phone), even if it is offered by the same service provider, for example Maxis customers switching to its I-phone service offering, and/or switching to another new package. As such, consumer innovativeness can be stimulated not only by the network services but also by other embedded products and service offerings. Hence, innovativeness in the mobile phone service context and its link to service loyalty are issues worthy of research.

After introducing the 'Mobile Number Portability' (MNP) regulation in Malaysia on the $15^{\text {th }}$ of October 2008, competition among the main players in the mobile phone service industries has become more intense (MCMC 2009). According to the IDC report (2007), it may cause an increase in consumer switching by up to 11.7 percent on a yearly basis. Although MNP lessened the barriers of service switching in the Malaysian mobile phone service market, other forms of switching costs still persist, such as loss costs, adaptation costs and move-in costs. Therefore, it is vital to examine the effects of service switching costs. However, this is an understudied issue in the Malaysian service context. Hence, this study tries to minimize this gap by veri- 
fying the service switching costs effect on loyalty.

Considering this, the present study attempts to examine the effect of consumer innovativeness, service quality, service switching costs and service satisfaction on service loyalty among the mobile phone service users. The rest of the paper is four fold. In the next section a literature review and the hypotheses development is discussed. The following section discusses the methodology adopted in this study, followed by our findings and discussion. The last section draws conclusions and elaborates further on any implications and future research directions.

\section{Theoretical Underpinning}

Theory plays a great role in utilizing the hypothetic-deductive technique (Greenwald and Pratkins 1988). In this type of research, hypotheses are formulated on the basis of theoretical assumptions, and then the derived hyp otheses are tested empirically (Kuhn 1962). As the present study has adopted the hypothetico-deductive method to achieve its research purpose, the Expectancy-Disconfirmation Theory (EDT) (Oliver 1980), as well as exploratory buyer behaviour theory (Baumgartner and Steenkamp 1996; Raju 1980) have been considered to support the proposed relationships among the study constructs.

The EDT suggests that consumer satisfaction is the consumers' overall evaluation of a product or service which derives from the comparison between the consumers' prepurchase expectations and the perceived service quality (Oliver 1980, 1997). According to Oliver (1997: 13), "Satisfaction is the consumer's fulfilment response". This fulfilled state is the function of the consumers' judgement of the overall service quality
(Anderson and Sullivan 2003; Zeithaml and Bitner 1996). Under this theory, consumers modify and update their overall attitude towards the service quality based on their satisfaction of this instance of use, and this consequently leads to an intention to continue (or discontinue) the services (Oliver 1981; Yen and Lu 2008). Hence, service quality and satisfaction became the centre of research interest as the determinants of loyalty (see Khatabi et al. 2002; Mittal and Lassar 1998). Moreover, this theory gives rise to the idea that the repurchase intention occurred as a post satisfaction outcome (Oliver 1997). Hence, the present study considers service quality (performance) as an antecedent of service satisfaction and service satisfaction as an antecedent of service loyalty/switching.

Borrowed from the field of psychology, the exploratory buyer behaviour theory has received considerably research attention as the 'desire for exploration' is one of the most useful motivating factors to influence buying behaviour (Baumgartner and Steenkamp 1996). According to Berlyne (1963: 287), "The exploratory responses modify the stimulation from sources that are already represented in the stimulus field, and they introduce stimulation from sources that were not hitherto represented". This theory postulates that certain stimuli have 'arousal potential' and sometimes animals and people are engaged in such activities that help to obtain the optimum level of arousal potential (Berlyne 1960, 1963). If the arousal potential is less than the optimum level, it may cause bore$\mathrm{dom}$ and thus to avoid the feeling of boredom, individuals tend to engage in seeking the stimuli which possess higher arousal potential (Raju and Venkatesan 1980). Moreover, exciting and novel experiences, the desire for change and variation as well as the 
desire to fulfill one's curiosity, also lead the individual to explore new and/or different products and services (Berlyne 1978). One of the major applications of this theory is to justify consumers' innovativeness in product adoption (Mittelstaedt et al. 1976) and variety seeking in product purchasing behaviour (McAlister and Pessimier 1982). Although consumer innovativeness has received considerable research attention in the field of consumer goods, comparatively less empirical studies have been conducted on the topic in services. The present study assumes that due to the influence of the exploratory component, consumer innovativeness can reduce the magnitude of service satisfaction as well as service loyalty. Thus, consumer innovativeness is considered as another influential antecedent of service satisfaction and loyalty in mobile phone service usage.

\section{Theoretical Framework and Hypotheses Development}

\section{Conceptual Framework}

In this study it is proposed that service quality, service satisfaction, and service switching costs positively affect service loyalty, whereas, consumer innovativeness negatively affects service loyalty. Furthermore, service satisfaction mediates the relationship between service quality and service loyalty.

\section{Service Loyalty}

Since its inception in the 1940s (see Guest 1942, 1944), the term 'loyalty' has received a considerable amount of research attention due to its various monetary and nonmonetary benefits accruing to firms' growth. Gaining competitive advantage (Bharadwaj et al. 1993), profitability, survival, success and growth,
(Reichheld 2002; Schultz 2005), and positive word of mouth (Woratschek and Horbel 2003; Zeithaml et al. 1996) are only the tip of the iceberg. Therefore, customer retention has become the holy grail in industries from airlines to wireless technologies (Bristow and Sebastian 2001; Coyles and Gokey 2005; Heskett 2002; Salegna and Goodwin 2005).

Guest (1944) and Churchill (1942) began to explore this phenomenon in the 1940s. Since then researchers have been trying to identify its nature, dimensions, antecedents, and consequences. Nowadays, many researchers perceive service loyalty as a multidimensional construct due to the importance and contribution of measuring service loyalty to greater depths. It is argued that the attitudinal-cognitive-conative-affective loyalty could strongly impact current and, more importantly, future consumer behaviour, which may be impossible to understand and difficult to predict without knowledge of these elements (Salegna and Goodwin 2005). Therefore, for the present study, service loyalty is conceptualized as a multidimensional construct guided by the definitions of Gremler and Brown (1996) and Oliver (1997).

Hence, this study conceptualizes service loyalty as 'the combination of behavioral, attitudinal, cognitive, affective and conative loyalty, while using the same mobile phone service provider's service for at least four months duration, and using one SP's services predominantly'. As four months of usage experience was found to be sufficient to establish reliable perceptions and opinions regarding the mobile phone service usage (Turel and Serenko 2006), the present study also considered this duration of usage experience to be loyal. In addition to this, in the context of other services (banks, credit card companies, firms that offer appliance repair 
Figure 1. Proposed Relationships among the Constructs

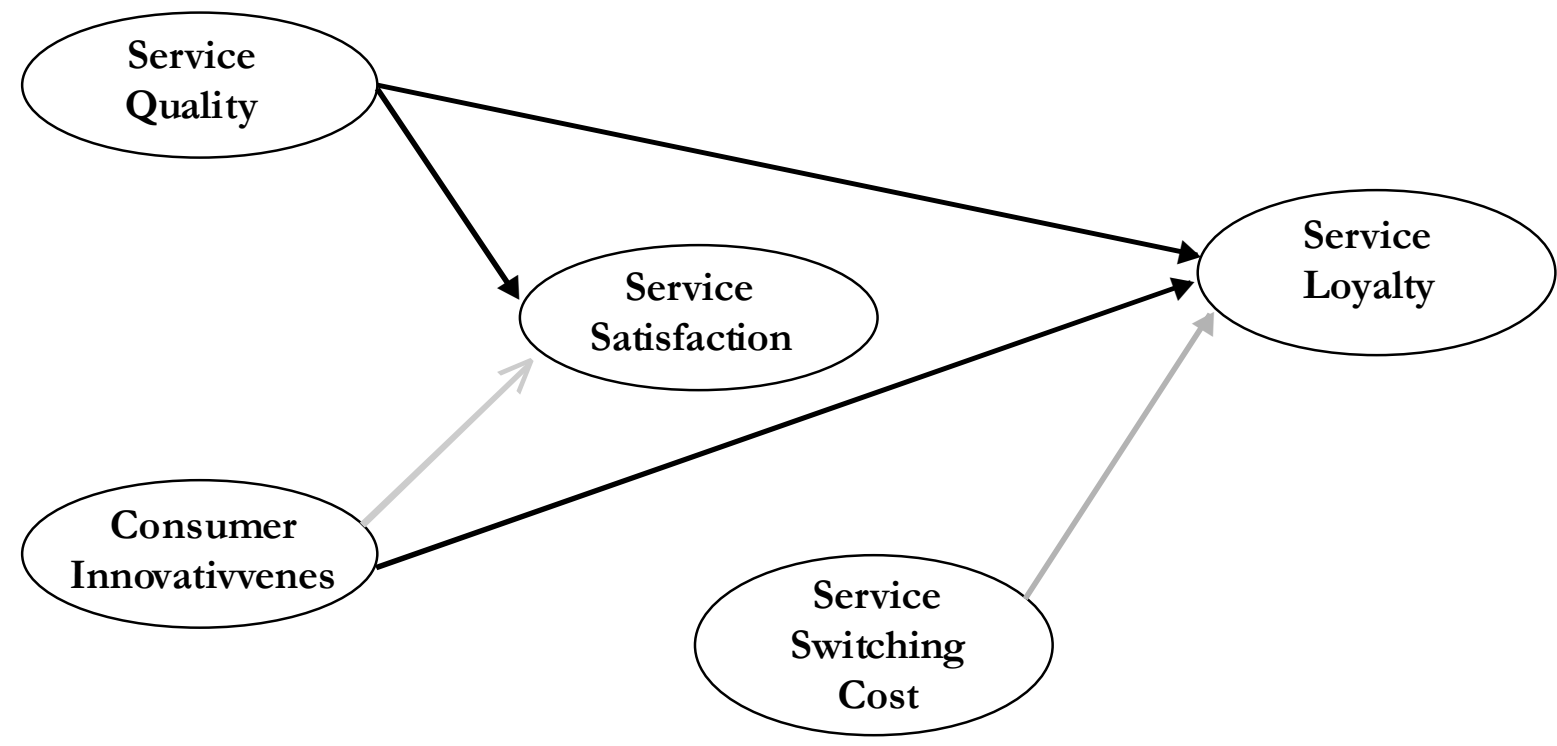

and maintenance services), Parasuraman et al. (1988) considered three months worth of experience in using these services as the qualifying criteria for the respondents.

\section{Consumer Innovativeness}

As stated by Hirschman (1980, p. 283), "Few concepts in the behavioral sciences have as much immediate relevance to consumer behavior as consumer innovativeness". It changes consumers' routinized buying tendencies into a more dynamic behavior (Hirschman 1980, 1984). Although consumer innovativeness has been studied in different contexts, such as wine consumption (Goldsmith et al. 1998), high-tech durable products (Kim et al. 2001), home entertainment equipment (Cowart et al. 2008), clothing purchases (Fowler and Bridges 2010), and the like, the literature has mainly addressed it for new products' adoption and diffusion processes (see Cowart et al., 2008; Greenhalgh et al. 2005; Hirunyawipada and Paswan 2006; Hoffmann and Soyez 2010) and there is not much discussion in the service literature.

It is important to note that 'service/ product innovativeness' and 'consumer innovativeness' are two totally different aspects of innovativeness. Another term for service/product innovativeness is the 'possession of newness' which takes a product perspective and refers to the goods/services acquiring some degree of 'newness' (Daneels and Kleinsmith 2001). On the other hand, consumer innovativeness or the 'consumption of newness' takes a consumer's perspective which implies a consumer's propensity to purchase new products or services frequently and rapidly (Midgley and Dowling 1978). The present study considers innovativeness exclusively from the consumers' perspective and defines it as the users' intrinsic motivation to explore different service offerings either from different service providers or even when offered by the same service provider. 


\section{Service Switching Cost}

The service switching cost is the penalty that consumers have to pay for changing service providers (Aydin et al. 2005). This phenomenon has been discussed in several fields such as economics, psychology, employee relations and marketing (Lin and Chou 2004; Zhu et al. 2011). Theoretically as well as empirically it is proven that switching costs contribute to repeat choice behavior (Weiss and Heide 1993), help to attain competitive advantage (Dubé et al. 2009; Klemperer 1995; Porter 1985), and enhance customers' levels of price-tolerance and decreases consumers' sensitivity to the shortrun fluctuations in customer satisfaction (Fornell 1992). Moreover, the switching cost is associated with higher profits (Beggs and Klempere 1992) and creates barriers to market entry (Karakaya and Stahl 1989). However, Fornell (1992) mentioned one potential disadvantage of the switching cost, that is the greater difficulty of capturing new customers when they are aware of the existence of barriers to them switching. Nonetheless, given its benefits, it seems that service firms need to manage their consumers' perception towards switching costs, and must utilize marketing activities to benefit from this switching penalty (Burnham et al. 2003).

\section{Service Satisfaction}

Consumer satisfaction has been the subject of many studies since the early 1970s (see LaTour and Peat 1979; Leavitt 1976). However, it is still the centre of attention for research into the field of marketing (Amin et al. 2013; Kursunluoglu 2014). Giese and Cote (2000) stated that consumer satisfaction is an emotive and/or cognitive response pertaining to a particular focus (expectations, product performance) which occurs after purchase, choice or product experience has occurred.

Satisfaction can be either cumulative (overall) or transaction-specific (Bodet 2008; Jones and Suh 2000). Transaction-specific satisfaction indicates consumers' satisfaction/ dissatisfaction judgements of a single purchase experience or a particular service encounter (Anderson et al. 1994; Boulding et al. 1993). On the other hand, cumulative satisfaction/dissatisfaction is viewed as an overall evaluation of the total purchase experience, or all previous service encounters with a particular product or service (Jones and Suh 2000). According to many researchers (e.g., Anderson et al. 1994; Bitner and Hubbert 1994; Olsen 2007), as overall satisfaction represents the consumers' aggregate state of their level of satisfaction/dissatisfaction, rather than a specific transaction evaluation, overall satisfaction outweighs transaction specific satisfaction. In this way, it serves as a more appropriate and useful measure of a firm's past, present and future performance evaluation criterion (Johnson et al. 2001; Oliver 1997). Following this convention, this study also considers service satisfaction as a cumulative process.

\section{Service Quality}

Three unique characteristics of service, i.e., intangibility, heterogeneity, and inseparability made service quality an elusive phenomenon to study (Parasuraman et al. 1985). The quality of physical products can be measured objectively using indicators such as counting the number of defects or measuring the durability of the products (Garvin 1983). However, evaluating service quality is more difficult than evaluating product quality (Aydin and Ozer 2005; Parasuraman et al. 1988). Furthermore, it become more 
complicated to evaluate since service quality is often linked with the service delivery process and its output (Cody and Hope 1999).

Service quality is a form of attitude which can be measured by assessing consumers' quality perceptions of service firms' efforts in fulfilling the service quality gaps. In addition, Gronroos (1984) defined service quality as what consumers receive (i.e., technical quality) and how they get the technical outcomes, i.e., functional quality. The nature of service quality differs in different service contexts, particularly, in the telecommunications service industry.

The term 'quality' began to receive wide attention from researchers in the 1980's (see Gronroos 1984; Parasuraman et al. 1985, 1988; Zeithaml 1988; Zeithaml et al. 1988) as it serves as a differentiating strategy for the service providers and helps in gaining and creating a competitive advantage (Leisen and Vance 2001). Ensuring a 'quality' service is equally important for telecommunications service providers, as well as for other service providers, to establish and to maintain loyal consumers (Izogo and Ogba 2015; Zeithaml 2000). It is more crucial for the technologybased services (Ahn et al. 2006; Habib et al. 2011; Kumar and Lim 2008; Lai et al. 2009) due to the fact that in the absence of a standard service quality, to sell the service is almost impossible (Seo et al. 2008). Moreover, in the telecommunications industry, service quality is considered as an essential performance measurement indicator (Shin and Kim 2008). Additionally, in this industry, the service delivery system has the ability to enable the service providers to get actual customer feedback, and to understand their levels of satisfaction with the delivered services (Johnson and Sirikit 2002). However, as service quality is abstract in nature (Parasuraman et al. 1985; Zeithaml and Bitner 2000), it is a great challenge for the telecommunications service providers to deliver high standard services in a consistent manner (Haque et al. 2007).

\section{Hypotheses Development}

\section{Ser vice Quality (Functional, Technical, Customer Relationship Competencies) and Service Loyalty}

Although the direct link between service quality and loyalty has been investigated in the telecommunications industry (Aydin and Ozer 2005; Eshghi et al. 2008; Lai et al. 2009) and in other service contexts (Ehigie 2006; Dean 2002; Kondasani and Panda 2015), these studies yielded mixed results, especially in the telecommunications industry. For example, Abod Ali et al. (2002) with the Digital (leased) line II service offered by Telekom Malaysia Berhad (TMB), Eshghi et al. (2008) with the Indian telecommunications service, and Aydin and Ozer (2005) with the Turkish GSM mobile phone service, found support for this relationship, whereas Lai et al. (2009) and Mohd Rafi et al. (2010) obtained insignificant results. Perhaps cultural idiosyncratic characteristics generated such variations in patterns and strengths of relationships across cultures (Clark 1990; Lai et al. 2009). Hence, the present research examines this relationship for post-paid users in the Malaysian mobile phone service context. Moreover, as most studies have found positive links between these two constructs, the present study also assumes that high service quality will result in high mobile phone service loyalty.

Furthermore, most of the telecommunications literature considered a measured 
service quality using the SERVQUAL dimension, ignoring the technical aspects of quality. It is argued that the structure of service quality measures varies depending on the nature and type of the different service industries (e.g., Babakus and Boller 1992; Cronin and Taylor 1992). Hence, taking a multi-dimensional perspective for service quality, based on the functional and technical aspects of quality, the present study hypothesized:

$H_{i}$ : The bigher the (a) technical quality, (b) functional quality and (c) customer relationship competencies perceived by the mobile phone service users are, the more likely it is that they will be loyal to a particular service provider.

\section{Service Quality (Functional, Technical, Customer Relationship Competencies) and Service Satisfaction}

In the field of consumer behavior, the expectancy-disconfirmation paradigm has contributed significantly in modelling customer satisfaction at the individual level, as well as on a national basis in Sweden (Fornell 1992), Canada (Turel and Serenko, 2006), USA (Fornell et al. 1996), and Turkey (Aydin and Ozer 2005). These models advocate considering service quality as an antecedent of service satisfaction. Using the EDT, Patterson (1993), Patterson et al. (1997), and Spreng et al. (1996), also support the use of performance perceptions (service quality) to measure satisfaction. Furthermore, on the basis of Chenet et al. (1999), Ennew and Binks (1999) and Woodruff's (1997) work, Lai et al. (2009, p. 981) suggested that "the more cognitively-oriented service quality and value appraisals may lead to emotive satisfaction."
Prior studies examined the link between service quality and service satisfaction and found support for this relationship across different cultures (see Brady and Robertson 2001; Chen et al. 2012; Davis-Sramek et al. 2009; Ehigie 2006; Ueltschy et al. 2007 Yuen and Thai 2015). However, past research did also yield mixed results when examining this relationship. For example, in studying the Greek banking sector, Athanassopoulos (1997) contended that perceived service quality results in service provider perceptions about customer satisfaction. Again, a study of a low-contact service context, which was servicing cars, Mittal and Lassar (1998) revealed that the service quality positively influenced customers' satisfaction. Similarly, Shin and Kim (2008) and Turkyilmaz and Ozkan (2007) found a significant direct association between service quality and customer satisfaction in the telecommunications industry. On the contrary, Harris and Goode (2004) found partial support, while Lai et al. (2009) and deRuyter et al. (1998) did not find any support for this relationship. Hence, to verify this relationship for mobile phone service usage, the present study hypothesized that:

$H_{2}$ : The higher the (a) technical quality, (b) functional quality and (c) customer relationship competencies perceived by mobile phone service users are, the more likely it is that they will be satisfied with a particular service provider.

\section{Service Satisfaction and Service Loyalty}

In the EDT, Oliver (1997) suggested that satisfaction is linked to post-purchase attitudes and repurchase intentions. Service research echoes this finding by providing more empirical evidence (see Ball et al. 2006; 
Cronin and Taylor 1992; Wang and Lo 2002). Although the positive relationship between satisfaction and loyalty has been proven to be true (Izogo and Ogba 2015; Kursunluoglu 2014; Mavri and Ioannou 2008; Quoquab et al. 2014; Yang and Peterson 2004), Mittal and Lassar (1998) raised an issue where a dissatisfied customer might still continue his/her patronage if there is no better product/service from alternative sellers, and satisfied customers might be willing to switch to competitors in the hope of gaining even more satisfying results. However, for the present study, considering the positive relationship between these two constructs it is hypothesized that:

$H_{3}:$ Hypothesis 3: The higher the service satisfaction is, the more likely it is that the mobile phone service users will be loyal to a particular service provider.

\section{Service Quality (Functional, Technical, and Customer Relationship Competencies), Service Satisfaction and Service Loyalty}

According to Zeithaml and Bitner (1996), customers' overall evaluation of service excellence is the major antecedent of customers' satisfaction. On the other hand, satisfaction is proven to be a significant predictor in explaining customers' loyalty (e.g., Fornell et al. 1996; Kondasani and Panda 2015; Yang and Peterson 2004). As such, satisfaction exhibits a mediating influence between service quality and service loyalty. The EDT also supports this notion (see Oliver 1980, 1997). Under this theory, consumers modify and update their overall attitude towards service quality based on their satisfaction of its use, and consequently this leads to an intention to continue using the service (Oliver 1981; Yen and Lu 2008).

A mediator variable helps in explaining bow or why a relationship persists between the predictor and outcome variable (Holmbeck 1997; Kim et al. 2001; Peyrot 1996). Therefore, it is more interesting to study a mediator variable, rather than studying the predictor variable alone (Bennett 2000). Hence, considering service satisfaction as a mediator between service quality and service loyalty, will generate a deeper understanding of the relationship by providing the answer to why or how this relationship exists.

The mediation effect of satisfaction between service quality and loyalty in the telecommunications industry (Turel and Seranko 2006) as well as in other studies (Caruana 2002; Cronin and Taylor 1992; Ishak et al. 2006) has already been examined. Moreover, the view of the mediating relationship of satisfaction between service quality and service loyalty is embedded in the Customer Satisfaction Index (CSI) models underlying the national satisfaction indices in several advanced countries (Aydin and Ozer 2005; Fornell et al. 1996; Turkyýlmaz and Ozkan 2007; Turel and Serenko 2006). However, it is not yet conclusive whether the mediating effect of satisfaction is also applicable in the Malaysian mobile phone service context. Moreover, most of these studies considered loyalty as a uni-dimensional construct and used SERVQUAL as a basis for measuring service quality. Therefore, considering loyalty as a multi-dimensional construct and combining technical, functional and customer relationship competency dimensions together, this study hypothesized that:

$H_{4}$ Service satisfaction mediates the relationship between (a) technique quality, (b) functional quality, and (c) customer relationship competencies and service loyalty. 


\section{Service Switching Cost and Service Loyalty}

Switching costs are the economic, psychological, and social agents that pose barriers when considering switching service providers (Aydin and Ozer 2005; Matzler et al. 2015; Park et al. 2014). Such costs are incorporated in both the product and service sectors. They have significant influence on whether one should continue or stop patronizing the current service provider (Chea and Luo 2005; Lin and Chou 2004). Different economic cost models into consumer behavior support this view (Hauser and Wernerfelt 1990; Payne 1982). Moreover, switching costs have been empirically proven as the antecedent of loyalty in different service contexts (Dagger and David 2012; Yang and Peterson 2004, Yen 2010), as well as in telecommunications literature (Aydin and Ozer 2005; Ayding et al. 2005; Matzler et al. 2015). However, further studies need to be carried out to examine this relationship in the setting of different service industries and different countries. Furthermore, as the use of mobile phone services is voluntary, requires a long term relationship, and physical proximity is less necessary, it is necessary to examine the effect of service switching costs on service loyalty, in order to understand how it varies from other services such as car insurance (obligatory use), health, education or law services (where physical proximity is a must).

Even though MNP makes it easier to switch service providers (Lee et al. 2006; Shin and Kim 2008), there is evidence of other kinds of service switching costs in the telecommunications market (Lee et al. 2006; Shin and Kim 2008). Therefore, after the implementation of the MNP regulation in Malaysia in the middle of October 2008, it is necessary to examine the effect of service switching costs on consumers' loyalty patterns. The following is thus hypothesized:

$H_{5}:$ The higher the service switching costs are, the more likely it is that the mobile phone service users will be loyal to a particular service provider.

\section{Consumer Innovativeness and Service Loyalty}

Based on the exploratory buyer behavior theory (Berlyne 1963), this research proposes that, 'consumer innovativeness' may have a negative influence on loyalty towards the service provider. It has been argued that innovative consumers are disposed to obtain more information and ideas about new products and services than others (Midgley and Dowling 1978). Not surprisingly, this type of consumer exhibits higher levels of aspiration for innovative and unique products and services and thus, they are likely to try new brands (Xie 2008). Cowart et al. (2008) also supported this view and stated that consumer innovativeness affects behavioral intentions for new products. Therefore, it is logical to assume that consumers who have a greater propensity to search for new ideas, information or 'newness' will become switchers, whereas those who have less or no propensity to search for 'newness' tend to be more loyal towards their brand or services. However, there is a dearth of research that examines the effect of consumer innovativeness on loyalty. Therefore, in an attempt to fill this gap, the following hypothesis is developed to verify its applicability in the context of mobile phone services:

$H_{6}:$ The higher the consumer innovativeness is, the less likely it is that the mobile phone service users will be loyal to a particular service provider. 


\section{Consumer Innovativeness and Service Satisfaction}

According to Midgley (1977), innovative-ness is an innate expression of a person's psychological or sociological characteristic. It is argued that, consumer innovativeness is the degree to which an individual makes innovative decisions independently of the communicated experience of others (Midgley and Dowling, 1978). As such, consumer innovativeness can be treated as a psychological characteristic that has a considerable effect on consumers' evaluation processes as well as their product/service choices.

The theory of exploratory buyer behavior suggests that the desire for exploration is one of the most useful motivating factors that influence buying behavior (Baumgartner and Steenkamp 1996; Raju 1980). Again, EDT advocates that expectations play a crucial role in the formation of a satisfaction judgement (Oliver 1980). In this process, disconfirmation occurs when there is a significant difference between an individual's initial expectations and the actual performance of the product/service (Jayanti and Jackson, 1991). Based on this argument, it can be assumed that individuals' whose innovativeness levels are high, are likely to explore more and expect more, and thus it is difficult to make them contented. Therefore, the following hypothesis is suggested:

$H_{7}$ : The higher the consumer innovativeness is, the less likely it is that the mobile phone service users will be satisfied with a particular service provider.

\section{Methods}

As the objective of this study is to examine the service loyalty and switching behavior of mobile phone service users, indeed the population consisted of individuals. The results of a survey conducted by the Malaysian Communications and Multimedia Commission (MCMC) (2005, 2006, and 2009) generated the idea that a major portion of the mobile phone users fall in two major categories: employed users (about 53\%) and students (almost 25\%). Hence, this study tried to capture both categories of users, that is, students and employed individuals as the subjects for this study; more specifically, academic and non-academic staff (including administrative, managerial, clerical and technical staff) and postgraduate students.

This study employed the drop-off method (self-administered) to administer the questionnaire. 1,050 questionnaires were distributed in seven high ranked universities located in the Klang Valley area, which yielded 535 valid usable completed responses. All scales to measure the study's constructs were borrowed from past literature using a 5 point Likert scale, where $1=$ 'strongly disagree' and $5=$ 'strongly agree.'

The scale to measure the service loyalty construct was borrowed from Jones and Taylor (2007). For the present study, the service loyalty construct was considered as a multi-dimensional construct which consists of behavioral loyalty, attitudinal loyalty, affective loyalty, cognitive loyalty and conative loyalty. However, in order to reduce the model's complexity, an item parcelling technique was utilized as suggested by past researchers (Kline 2005; Little et al. 2002). Parcelling is a measurement practice that is used most commonly in multivariate approaches to psychometrics, particularly for use with latent-variable analysis techniques (Little et al. 2002). It is a total score across a set of homogeneous items (i.e., it is a mini scale) (Kline 2005). The decision whether or not to parcel depends on the researcher's 
philosophical position (Little et al. 2002). This technique has received research interest due to its numerous benefits, such as (1) it may provide a useful approximation to continuous scales, (2) it provides a more stable result than is often obtained with item-based analyses, and (3) it creates indicators with greater reliability and more definitive rotational results (Cattell and Burdsal 1975)

In the present study, the item parcelling method was used for the service loyalty and service switching constructs due to three reasons: (1) to simplify the complex research model while maintaining the large number of items for the service loyalty construct (Garver and Mentzer 1999; Hair et al. 2006), (2) to avoid the distortion by idiosyncratic characteristics of individual items (Little et al. 2002), and (3) to make the data conform to the assumption of normality as required in an SEM estimation (Little et al. 2002). In essence, the main focus was to achieve a more parsimonious estimation by using this process.

In the present study, the parcelling procedure was carried out based on content similarity, rational grounds, observing the internal consistency, and factor loadings and the model's fit of the construct's measurement model. More clearly, once the content similarity and theoretical rational have been established, the internal consistency was proven to meet the required expectations $(\alpha>0.7)$, and the CFA results of the construct showed a good factor loading and overall model fit, the items were parcelled.

Researchers should be aware that parcelling requires items within each set to be uni-dimensional, which means that they are known to measure a single construct (Bandalos and Finney 2001). This knowledge may come from familiarity with the item domain (Hair et al. 2006; Kline 2005) or as the result of prior statistical analysis that indicates uni-dimensional measurements (Kline 2005). In this study, uni-dimensionality was assured from the cursory review of past literature. Moreover, as recommended by Hair et al. (2006), prior to our parcel, CFA was performed on the individual factors to check for uni-dimensionality, to see (1) whether the constructs were reflected by all the individual items related to the other constructs and (2) was a construct reflected by a smaller number of parcels During this process, items with a low loading and cross-loading into the other variables were deleted to assure uni-dimensionality. After it was found that items were highly loaded (mostly 0.8 and above), item parcelling was performed.

The scale to measure technical quality and functionality was borrowed from Kim et al. (2004), whereas, the customer relationship competencies scale was borrowed from Lai et al. (2007). Lai et al.'s (2007) customer relationship competencies scale was developed based on Parasuraman et al.'s (1988) scale. Since Kim et al.'s (2004) scale does not cover all aspects of functional quality, Lai et al.'s (2007) scale was also incorporated, in order to address the greater number of service quality features. Additionally, the service switching costs and service satisfaction scales were adapted from Aydin and Ozer (2005). Lastly, the consumer innovativeness scale was borrowed from Raju (1980). All items to measure the study's constructs are shown in Table 1.

The Statistical Package for Social Science (SPSS) Version 17.0 (SPSS Inc. 19932007) for Windows statistical software and Structural Equation Modeling (SEM) using AMOS 20 were used to analyze the data. SPSS was used to compute the descriptive statistics and to perform reliability tests, whereas the Analysis of Moment Structures 
Table 1. Items to Measure the Study Constructs

\begin{tabular}{|c|c|}
\hline Constructs & Items \\
\hline Service Loyalty & 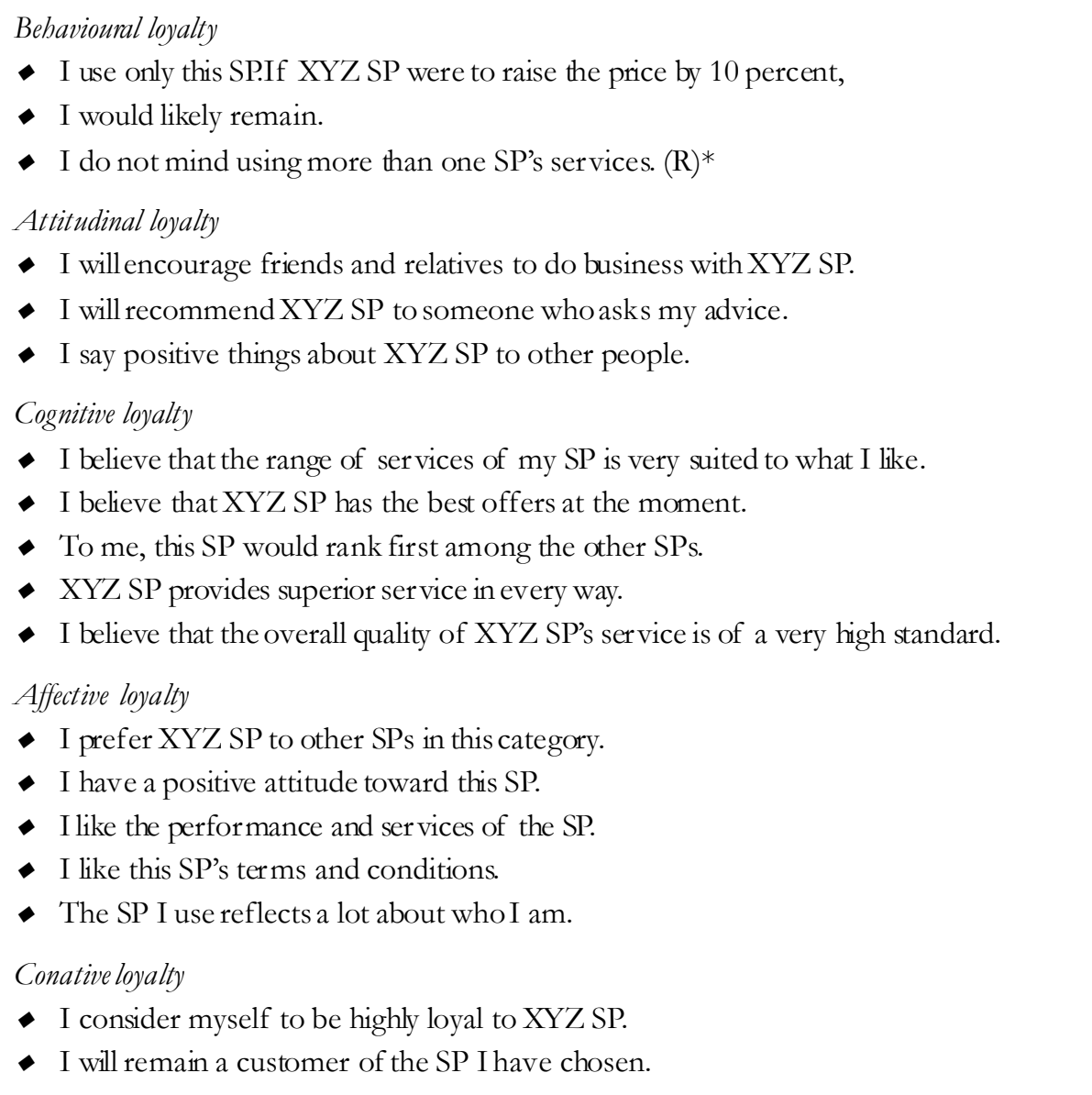 \\
\hline Service Quality & $\begin{array}{l}\text { Technical quality } \\
\text { - I get a variety of value added services from my SP. } \\
\text { - The offered value added services are easy to use. } \\
\text { Functional quality } \\
\text { - The offered value added services are up-to-date. } \\
\text { - I get adequate customer support from my SP. } \\
\text { - The speed of complaint processing is satisfactory. } \\
\text { - It is easy to report my complaint to my SP. } \\
\text { Customer Relationship Competencies } \\
\text { - The service provided by the company is prompt (low waiting time and quick response). } \\
\text { - Employees are efficient and competent, knowledgeable and skilful. } \\
\text { - Employees are courteous, polite and respectful. } \\
\text { - The company provides individual and personal attention to the customers. } \\
\text { The operating hours are convenient for the customers. }\end{array}$ \\
\hline
\end{tabular}


Table 1. Continued

\begin{tabular}{|c|c|}
\hline Constructs & Items \\
\hline Service Satisfaction & $\begin{array}{l}\text { I am fully satisfied with XYZ SP. } \\
\text { - When I have experienced unforeseen or critical situations, XYZ SP has managed these } \\
\text { in a satisfactory manner. } \\
\text { - This SP meets my pre-purchase expectations. } \\
\text { - I am happy with the efforts this SP is making towards regular consumers like me. }\end{array}$ \\
\hline Service Switching Costs & $\begin{array}{l}\text { If I switch to a new SP, I would lose loyalty points, bonus Ringgits etc. that I have } \\
\text { gained with my current SP. } \\
\text { - If I switch to a new SP, with a technology upgrade, I could not use some services until I } \\
\text { learn to use the new phone and services effectively. } \\
\text { - If I switch to a new SMART phone offer, I could not use some services until I learn to } \\
\text { use the new phone and services effectively. } \\
\text { - Comparing information regarding all SP's offerings with one another takes a lot of } \\
\text { energy, time and effort. }\end{array}$ \\
\hline Consumer Innovativeness & $\begin{array}{l}\text { I would get tired of using my SP for a long time because the SP does not have any good } \\
\text { offers compared to other competitors' offers. } \\
\text { - I like to switch my SP to try something different. } \\
\text { When I see that new features/options provided by other SPs are somewhat different } \\
\text { from the usual, I intend to try it. } \\
\text { I I like to experience newness and change in my SP's services and offerings. }\end{array}$ \\
\hline
\end{tabular}

(AMOS) Version 5.0 (Arbuckle 1994-2003) with Maximum Likelihood Estimation (MLE) was utilized to perform Confirmatory Factor Analysis (CFA) and covariance structure analysis or SEM.

\section{Findings and Discussion}

\section{Profile of the Respondents}

The study sample comprised respondents who varied in gender, age, marital status, profession, income, ethnicity, and level of education. More than 50 percent of the respondents were female $(59.8 \%)$. Most of the respondents ages (51\%) were between 18 and 31 years. The majority of the participants were Malays (58.1\%) and married (49.7\%). With respect to their educational background, the bulk of the respondents have a master's degree $(32.9 \%)$. And the results of the descriptive analysis show that 28 percent of the participants have a income ranging between RM 2001 and RM 3500 per month.

\section{Correlation Analysis}

In this study, correlation was used to assess the degree of association among the variables, and to detect bivariate multicollinearity. According Tabachnick and Fidell (1989), association values that exceed 0.9 indicate multicollinearity. Table 3 exhibits the bivariate correlation with a two-tailed test of significance $\mathrm{p}<0.01$ and $\mathrm{p}<0.05$ for all the variables involved in this study. The correlation results between variables show positive and negative significant associations at $(p<0.01)$. Moreover, none of these values 
Table 2. Profile of the Respondents

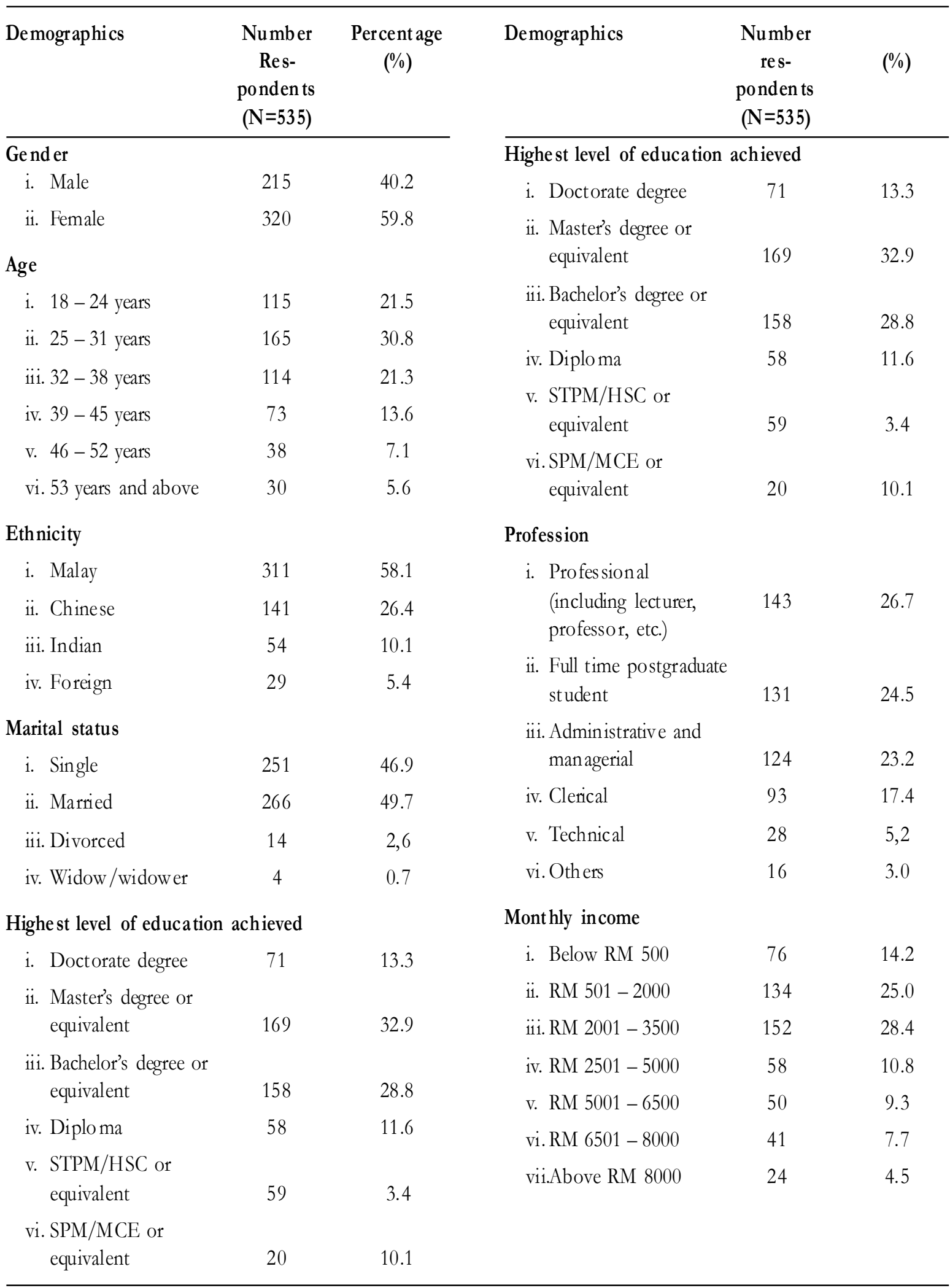


Table 3. Correlation Results for Observed Variables

\begin{tabular}{|c|c|c|c|c|c|c|c|}
\hline & SL & SS & TQ & FQ & CRC & SSC & CI \\
\hline \multicolumn{8}{|l|}{ Service } \\
\hline Loyalty (SL) & 1 & & & & & & \\
\hline \multicolumn{8}{|l|}{ Service } \\
\hline Satisfaction (SS) & $0.437 * *$ & 1 & & & & & \\
\hline \multicolumn{8}{|l|}{ Technical } \\
\hline Quality (TQ) & $0.411 * *$ & $0.250 * *$ & 1 & & & & \\
\hline \multicolumn{8}{|l|}{ Functional } \\
\hline Quality (FQ) & $0.502^{* *}$ & $0.434^{* *}$ & $0.331^{* *}$ & 1 & & & \\
\hline \multicolumn{8}{|l|}{ Customer } \\
\hline \multicolumn{8}{|l|}{ Relationship } \\
\hline Competencies (CRC) & $0.477^{* *}$ & $0.586^{* *}$ & $0.321^{* *}$ & $0.637^{* *}$ & 1 & & \\
\hline \multicolumn{8}{|l|}{ Service Switching } \\
\hline Cost (SSC) & $0.204^{* *}$ & $0.217^{* *}$ & $0.164 * *$ & $0.149 * *$ & $0.176^{* *}$ & 1 & \\
\hline \multicolumn{8}{|l|}{ Consumer } \\
\hline Innovativeness (CI) & $-0.160 * *$ & $-0.181 * *$ & $-0.125^{* *}$ & $-0.113^{* *}$ & $-0.138^{* *}$ & $-0.106^{*}$ & 1 \\
\hline
\end{tabular}

$* \mathrm{P}<0.05, * * \mathrm{p}<0.01$

exceed 0.90 which means multicollinearity was not a problem in this study.

\section{Measurement Model}

Analysis of the full measurement model was done by correlating all variables involved in the structural model. Every variable is assumed to be correlated with each other. Modification indices and the standardized residual were examined to see whether there was any misspecification in the model to fulfill the requirement for the uni-dimensionality of the constructs (Byrne 2010). The result of the goodness of fit measures indicates a well-fitting model with $\chi^{2} / \mathrm{df}=2.689$; $\mathrm{GFI}=0.882$; AGFI $=0.856$; $\mathrm{TLI}=0.924$; $\mathrm{CFI}=0.934$; $\mathrm{NFI}=0.901 ; \mathrm{IFI}=0.934 ;$ and RMSEA $=$ 0.056 .

\section{Convergent Validity}

From the inspection of the standardized regression weight, it was found that all the items were significantly loaded into their intended factors with standard loadings ranging from 0.467 to 0.946 (see Table 4) (Churchill 1979), which assures convergent validity. In CFA, the critical ratio for factor loadings is often used to assess convergent validity. Table 4 also indicates that the Critical Ration (CR) for all estimated parameters exceeded the \pm 1.96 benchmark (Arbuckle and Wothke 1999), which were also found to be statistically significant.

The results of the AVE calculation shown in Table 5 reveals that variance extracted for all the constructs ranged from 
Table 4. Testing Convergent Validity on the Basis of Factor Loadings

\begin{tabular}{|c|c|c|c|}
\hline Factors/Items & Standard Loading & Critical Ration & P Value \\
\hline Conative Loyalty $\leftarrow$ Loyalty & 0.795 & & \\
\hline Affective Loyalty $\leftarrow$ Loyalty & 0.920 & 23.950 & *** \\
\hline Cognitive Loyalty $\leftarrow$ Loyalty & 0.746 & 18.591 & $* * *$ \\
\hline Attitudinal Loyalty $\leftarrow$ Loyalty & 0.504 & 11.748 & $* * *$ \\
\hline Behavioural Loyalty $\leftarrow$ Loyalty & 0.799 & 20.317 & $* * *$ \\
\hline FQ59 $\leftarrow$ Functional Quality & 0.796 & & \\
\hline FQ58 $\leftarrow$ Functional Quality & 0.790 & 19.182 & $* * *$ \\
\hline FQ57 $\leftarrow$ Functional Quality & 0.724 & 17.308 & $* * *$ \\
\hline FQ60 $\leftarrow$ Functional Quality & 0.826 & 20.167 & $* * *$ \\
\hline SC77 $\leftarrow$ Service Switching Cost & 0.467 & & \\
\hline SC75 $\leftarrow$ Service Switching Cost & 0.846 & 10.794 & $* * *$ \\
\hline SC74 $\leftarrow$ Service Switching Cost & 0.832 & 10.744 & $* * *$ \\
\hline SC73 $\leftarrow$ Service Switching Cost & 0.861 & 10.845 & $* * *$ \\
\hline CI93 $\leftarrow$ Consumer Innovativeness & 0.783 & & \\
\hline CI92 $\leftarrow$ Consumer Innovativeness & 0.929 & 21.777 & $* * *$ \\
\hline CI88 $\leftarrow$ Consumer Innovativeness & 0.777 & 19.045 & $* * *$ \\
\hline CI86 $\leftarrow$ Consumer Innovativeness & 0.538 & 12.438 & $* * *$ \\
\hline SS85 $\leftarrow$ Service Satisfaction & 0.856 & & \\
\hline SS84 $\leftarrow$ Service Satisfaction & 0.921 & 29.600 & $* * *$ \\
\hline SS83 $\leftarrow$ Service Satisfaction & 0.901 & 28.412 & $* * *$ \\
\hline SS82 $\leftarrow$ Service Satisfaction & 0.854 & 25.743 & $* * *$ \\
\hline $\mathrm{SQ71} \leftarrow \mathrm{CRC}$ & 0.628 & & \\
\hline $\mathrm{SQ70} \leftarrow \mathrm{CRC}$ & 0.818 & 15.169 & $* * *$ \\
\hline $\mathrm{SQ} 69 \leftarrow \mathrm{CRC}$ & 0.838 & 15.417 & $* * *$ \\
\hline SQ68 $\leftarrow$ CRC & 0.823 & 15.228 & $* * *$ \\
\hline SQ66 $\leftarrow$ CRC & 0.639 & 12.587 & $* * *$ \\
\hline TQ53 $\leftarrow$ Technical Quality & 0.946 & & \\
\hline TQ52 $\leftarrow$ Technical Quality & 0.901 & 35.331 & $* * *$ \\
\hline TQ54 $\leftarrow$ Technical Quality & 0.899 & 35.122 & $* * *$ \\
\hline
\end{tabular}

Table 5. Variance Extracted of Indicators

\begin{tabular}{lccllc}
\hline Constructs & Variance extracted & & Constructs & Variance extracted \\
\cline { 1 - 2 } \cline { 5 - 6 } Benchmark Value & Threshold level $\geq \mathbf{0 . 5}$ & & Benchmark Value & Threshold level $\geq \mathbf{0 . 5}$ \\
\cline { 1 - 2 } \cline { 5 - 6 } Behavioural loyalty & 0.841 & & Technical quality & 0.838 \\
Attitudinal loyalty & 0.652 & & Functional quality & 0.616 \\
Cognitive loyalty & 0.566 & & Customer relationship & 0.570 \\
Affective loyalty & 0.568 & & competencies & \\
Conative loyalty & 0.723 & & Service Switching cost & 0.605 \\
Service satisfaction & 0.763 & & Consumer innovativeness & 0.593 \\
\hline
\end{tabular}


0.558 to 0.841 which exceeded the recommended threshold level of 0.5 (Hair et al. 2006) These results show that variance due to measurement error was smaller than variance captured by the constructs and thus falls within the acceptable range of the validity of the constructs.

In assessing the reliability of the latent variables, utilizing the composite reliability is a better option than using only Cronbach's coefficient alpha, as it is argued that Cronbach's coefficient alpha ignores the unique contribution of each indicator variable and assumes the equal error variance for all the indicators of a construct (Cortina 1993). Therefore, in this study the results of the constructs' reliability (composite reliability), which is often used in conjunction with SEM models (Hair et al. 2006) are presented in Table 6 , in order to prove that convergent validity exist for the constructs of the study.

Table 6. Construct Reliability

\begin{tabular}{lc}
\hline Constructs & Composite Reliability \\
\hline Benchmark Value & Threshold Level $\geq \mathbf{0 . 5}$ \\
Behavioural loyalty & 0.939 \\
Attitudinal loyalty & 0.848 \\
Cognitive loyalty & 0.866 \\
Affective loyalty & 0.855 \\
Conative loyalty & 0.840 \\
Service satisfaction & 0.927 \\
Technical quality & 0.940 \\
Functional quality & 0.954 \\
CRC & 0.866 \\
Service Switching cost & 0.855 \\
Consumer innovativeness & 0.850 \\
\hline
\end{tabular}

Here, standardized loadings can be obtained from the AMOS output, and $\varepsilon_{j}$ is the measurement error for each indicator. The measurement error is calculated as 1.0 minus the reliability of the indicator (the square of the indicator's standardized loading). The results given in Table 6 suggest that all composite reliability values were above the threshold level of 0.7 . Hence, convergent validity and construct reliability were assured.

\section{Discriminant Validity}

Discriminant validity exists when unidimensionality is confirmed among the variables. In this regard, the results of the individual CFA and full measurement model indicate that all the items were significantly loaded into their intended factors with a standard loading. Moreover, following the suggestion of Jöreskog (1971) and Bagozzi and Phillips (1982), the chi-square difference tests were employed for an eight-factor model (the measurement model) which was compared against seven-factor, five-factor, four-factor, two-factor, and one-factor models. The results shown in Table 7 indicate the significant chi-square differences. The critical value $\left(\Delta \chi^{2}>3.84, \mathrm{df}=1\right)$ is exceeded in all cases and hence assures the presence of discriminant validity.

The measurement model was treated as a seven-factor model. Again, in the five-factor model, all three service quality dimensions were loaded into one factor, while in the fourfactor model, service satisfaction was loaded with service loyalty and service switching. Furthermore, in the two-factor model, service quality, service switching costs and consumer innovativeness were loaded together. Lastly, in the one-factor model, all the items were loaded into a single factor. 
Table 7. Test for Discriminant Validity - CFA Comparison of the Measurement Models

\begin{tabular}{|c|c|c|c|c|c|c|c|c|c|c|c|}
\hline Model & $\chi^{2}$ & df & $\Delta \chi^{2}$ & $\Delta \mathrm{df}$ & GFI & AGFI & TLI & CFI & NFI & IFI & RMSEA \\
\hline $\begin{array}{l}\text { 7-Factor } \\
\text { Model }\end{array}$ & $1,174.808$ & 413 & - & - & 0.873 & 0.847 & 0.917 & 0.927 & 0.892 & 0.927 & 0.059 \\
\hline $\begin{array}{l}\text { 5-Factor } \\
\text { Model }\end{array}$ & $2,821.078$ & 424 & $1,646.27$ & 11 & 0.739 & 0.695 & 0.746 & 0.769 & 0.740 & 0.770 & 0.103 \\
\hline $\begin{array}{l}\text { 4-Factor } \\
\text { Model }\end{array}$ & $3,789.638$ & 428 & 968.56 & 4 & 0.646 & 0.590 & 0.648 & 0.676 & 0.650 & 0.677 & 0.121 \\
\hline $\begin{array}{l}\text { 2-Factor } \\
\text { Model }\end{array}$ & $5,724.572$ & 433 & $1,934.93$ & 5 & 0.550 & 0.484 & 0.452 & 0.490 & 0.472 & 0.491 & 0.151 \\
\hline $\begin{array}{l}\text { 1-Factor } \\
\text { Model }\end{array}$ & $6,411.624$ & 434 & 687.052 & 1 & 0.518 & 0.449 & 0.382 & 0.423 & 0.408 & 0.425 & 0.161 \\
\hline
\end{tabular}

\section{Structural Model}

The structural model was tested after getting adequate information to allow us to proceed from the previous series of analyses, such as assessing the SEM requirement, examining the measurement models' fit, reliability tests, convergence and discriminant analysis, and mediation effect analyses. The hypothesized relationships of the structural model were tested based on the goodness of fit indices. The result indicates that the hypothesized model has an acceptable fit with $\chi^{2} / \mathrm{df}=2.491 ; \mathrm{GFI}=0.90 ;$ AGFI $=0.866 ;$ $\mathrm{CFI}=0.942 ; \mathrm{TLI}=0.933$; NFI $=0.907$; IFI $=0.942$; and RMSEA $=0.053$. The structural model is shown in Figure 2.

A summary of the standardized path coefficients for the structural model is presented in In Table 1, the hypothesized relationships under examination for the present study, the standard errors of estimates, and the critical ratios for estimates that are associated with the $p$-values are presented. Following the common practices in the previous literature, to accept the hypotheses, $p$-values $<0.001$ (considering 99.9\% confidence interval and denoted as ${ }^{* * *}$ ), $p<0.01$ (considering $99 \%$ confidence interval and denoted as ${ }^{* *}$ ), $p<0.05$ (considering $95 \%$ confidence interval and denoted as $*$ ), and $p<0.1$ (considering $90 \%$ confidence interval and denoted as †) are considered (see Ahn et al. 2006; Bagozzi and Yi 1988; Shin and Kim 2008).

\section{Mediation Effect Test}

The first three mediation tests were conducted to examine the relationship among functional quality $\rightarrow$ service satisfaction $\rightarrow$ service loyalty, and technical quality $\rightarrow$ service satisfaction $\rightarrow$ service loyalty and CRC $\rightarrow$ service satisfaction $\rightarrow$ service loyalty. In short, service satisfaction was treated as the mediator in the relationship between the three dimensions of service quality and service loyalty. The results in Tables 8, 9 and 10 show the mediation test results among the stated relationships. For all three tests, the results indicate a significantimprovement of fit from the partially mediated model to fully mediated model $\left(\Delta \chi^{2}=42.716, \Delta \chi^{2}=71.595\right.$, $\Delta \chi^{2}=9.622$ respectively) and also a significant improvement between the partially-mediated model and the non-mediated model $\left(\Delta \chi^{2}=66.786 ; \Delta \chi^{2}=28.716 ; \Delta \chi^{2}=34.198\right.$ respectively). Since all comparisons showed a significant improvement, an examination of 
Figure 2. Structural Model

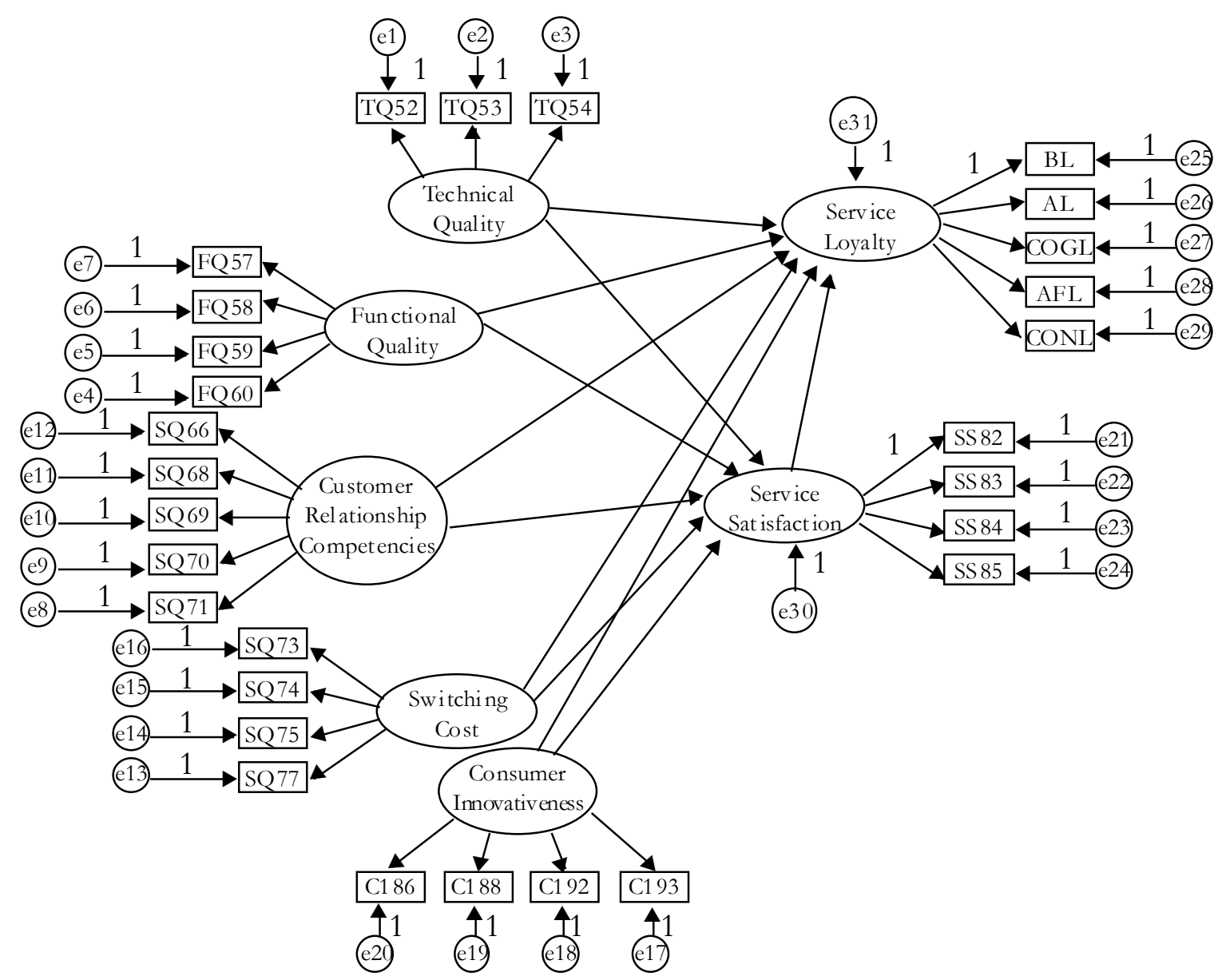

$\chi^{2} / \mathrm{df}=2.491 ; \mathrm{GFI}=0.9 ; \mathrm{AGFI}=0.866 ; \mathrm{CFI}=0.942 ; \mathrm{TLI}=0.933 ; \mathrm{NFI}=0.907 ; \mathrm{IFI}=0.942 ; \mathrm{RMSEA}=0.053$

Note: *** significant at $\mathrm{p}<0.001, * *$ significant at $\mathrm{p}<0.01, *$ significant at $\mathrm{p}<0.05$, $\dagger$ significant at $\mathrm{p}<0.1$.

ns: not significant, e: error term, and res: residual.

Table 8. Technical Quality $\rightarrow$ Service Satisfaction $\rightarrow$ Service Loyalty

\begin{tabular}{|c|c|c|c|c|c|c|c|c|c|c|}
\hline Model & $\chi^{2}$ & df & $\Delta \chi^{2}$ & GFI & AGFI & TLI & CFI & NFI & IFI & RMSEA \\
\hline $\begin{array}{l}\text { Model } 1 \\
\text { (FM) }\end{array}$ & 293.286 & 50 & $42.716^{*}$ & 0.915 & 0.867 & 0.937 & 0.952 & 0.943 & 0.952 & 0.095 \\
\hline $\begin{array}{l}\text { Model } 2 \\
(\mathrm{PM})\end{array}$ & 250.570 & 49 & - & 0.928 & 0.885 & 0.947 & 0.960 & 0.951 & 0.961 & 0.088 \\
\hline $\begin{array}{l}\text { Model } 3 \\
\text { (NM) }\end{array}$ & 317.350 & 50 & $66.786^{*}$ & 0.916 & 0.868 & 0.931 & 0.947 & 0.938 & 0.948 & 0.100 \\
\hline
\end{tabular}


the goodness of fit of the nested model lationship between technical quality and serneeded to be done to identify the best model. Based on an examination of the result of the goodness of fit indices, it is ascertained that service satisfaction partially mediates the revice loyalty, and also between functional quality and service loyalty, whereas it fully mediates the relationship between CRC and service loyalty.

Table 8. Technical Quality $\rightarrow$ Service Satisfaction $\rightarrow$ Service Loyalty

\begin{tabular}{lcccccccccc}
\hline Model & $\chi^{2}$ & df & $\Delta \chi^{2}$ & GFI & AGFI & TLI & CFI & NFI & IFI & RMSEA \\
\hline $\begin{array}{l}\text { Model 1 } \\
\text { (FM) }\end{array}$ & 293.286 & 50 & $42.716^{*}$ & 0.915 & 0.867 & 0.937 & 0.952 & 0.943 & 0.952 & 0.095 \\
$\begin{array}{l}\text { Model 2 } \\
\text { (PM) }\end{array}$ & 250.570 & 49 & - & 0.928 & 0.885 & 0.947 & 0.960 & 0.951 & 0.961 & 0.088 \\
$\begin{array}{l}\text { Model 3 } \\
\text { (NM) }\end{array}$ & 317.350 & 50 & $66.786^{*}$ & 0.916 & 0.868 & 0.931 & 0.947 & 0.938 & 0.948 & 0.100 \\
\hline
\end{tabular}

Table 9. Functional Quality $\rightarrow$ Service Satisfaction $\rightarrow$ Service Loyalty

\begin{tabular}{lcccccccccc}
\hline Model & $\chi^{2}$ & df & $\Delta \chi^{2}$ & GFI & AGFI & TLI & CFI & NFI & IFI & RMSEA \\
\hline $\begin{array}{l}\text { Model } 1 \\
\text { (FM) }\end{array}$ & 316.238 & 62 & $71.595^{*}$ & 0.917 & 0.878 & 0.932 & 0.946 & 0.934 & 0.946 & 0.088 \\
$\begin{array}{l}\text { Model } 2 \\
\text { (PM) }\end{array}$ & 244.643 & 61 & - & 0.933 & 0.901 & 0.950 & 0.961 & 0.949 & 0.961 & 0.075 \\
$\begin{array}{l}\text { Model } 3 \\
(\mathrm{NM})\end{array}$ & 273.359 & 62 & $28.716^{*}$ & 0.929 & 0.896 & 0.943 & 0.955 & 0.943 & 0.955 & 0.080 \\
\hline
\end{tabular}

Table 10. CRC $\rightarrow$ Service Satisfaction $\rightarrow$ Service Loyalty

\begin{tabular}{lcccccccccc}
\hline Model & $\chi^{2}$ & df & $\Delta \chi^{2}$ & GFI & AGFI & TLI & CFI & NFI & IFI & RMSEA \\
\hline $\begin{array}{l}\text { Model 1 } \\
\text { (FM) }\end{array}$ & 336.913 & 74 & $9.622^{*}$ & 0.918 & 0.883 & 0.936 & 0.948 & 0.934 & 0.948 & 0.082 \\
$\begin{array}{l}\text { Model 2 } \\
\text { (PM) }\end{array}$ & 346.535 & 73 & - & 0.913 & 0.875 & 0.932 & 0.946 & 0.932 & 0.946 & 0.084 \\
$\begin{array}{l}\text { Model 3 } \\
\text { (NM) }\end{array}$ & 380.733 & 74 & $34.198^{*}$ & 0.909 & 0.870 & 0.925 & 0.939 & 0.926 & 0.939 & 0.088 \\
\hline
\end{tabular}




\section{Discussion}

All the hypotheses and their test results are shown in Table 11. The results suggest that only two dimensions of service quality (technical and functional) are positively and significantly related to service loyalty $(\beta=$ $0.184, \mathrm{p}<0.001$ and $\beta=0.361, \mathrm{p}<0.001$ respectively). Hence hypotheses $H_{1 d}, H_{1 b}$ are supported. On the other hand, customer relationship competency is not significantly related to service loyalty thus, $H_{1 c}(\beta=0.015$, $\mathrm{p}=0.829)$ is rejected. The plausible explanation for this may be due to the reason that, unlike pre-paid users, post-paid users may feel very little need for customer relationship competencies from their SPs, as they seldom interact with the mobile phone service staff. Furthermore, customer support and convenient procedures (functional quality) seem to be more important to them, instead of responsiveness, assurance and empathy. This finding is also supported by Lai et al. (2009). They reported that SERVQUAL dimensions did not substantiate the quality-loyalty relationship in the Chinese telecommunications context.

Table 11. Summary of the Hypotheses Test Results

No. Relationships $\begin{gathered}\text { Expected } \\ \text { Direction }\end{gathered}$ Estimate Pvalue Result

\begin{tabular}{lccccc}
\hline $\mathrm{H}_{1 \mathrm{a}}$ & TQ $-\mathrm{L}$ & $+\mathrm{ve}$ & 0.184 & $* * *$ & Supported *** \\
$\mathrm{H}_{1 \mathrm{~b}}$ & $\mathrm{FQ}-\mathrm{L}$ & $+\mathrm{ve}$ & 0.361 & $* * *$ & Supported *** \\
$\mathrm{H}_{1 \mathrm{C}}$ & $\mathrm{CRC}-\mathrm{L}$ & $+\mathrm{ve}$ & 0.015 & 0.829 & Not supported \\
$\mathrm{H}_{2 \mathrm{a}}$ & $\mathrm{TQ}-\mathrm{Sat}$ & $+\mathrm{ve}$ & 0.111 & 0.007 & Supported $* *$ \\
$\mathrm{H}_{2 \mathrm{~B}}$ & $\mathrm{FQ}-\mathrm{Sat}$ & $+\mathrm{ve}$ & 0.112 & 0.072 & Supported $\dagger$ \\
$\mathrm{H}_{2 \mathrm{C}}$ & $\mathrm{CRC}-\mathrm{Sat}$ & $+\mathrm{ve}$ & 0.515 & $* * *$ & Supported $* * *$ \\
$\mathrm{H}_{3}$ & $\mathrm{Sat}-\mathrm{L}$ & $+\mathrm{ve}$ & 0.222 & $* * *$ & Supported $* * *$ \\
$\mathrm{H}_{5}$ & $\mathrm{SC}-\mathrm{L}$ & $+\mathrm{ve}$ & 0.094 & 0.023 & Supported \\
$\mathrm{H}_{6}$ & $\mathrm{CI}-\mathrm{L}$ & $-\mathrm{ve}$ & -0.038 & 0.343 & Not supported \\
$\mathrm{H}_{7}$ & $\mathrm{CI}-\mathrm{Sat}$ & $-\mathrm{ve}$ & -0.161 & $* * *$ & Supported \\
\hline
\end{tabular}

\section{Indirect relationships}

\begin{tabular}{lccc}
\hline H4a & TQ - Sat - L & Table 8 & Partial mediation \\
H4b & FQ - Sat - L & Table 9 & Partial mediation \\
H4c & CRC - Sat - L & Table 10 & Full mediation \\
\hline
\end{tabular}

Note: *** significant at $\mathrm{p}<0.001$

$* *$ significant at $\mathrm{p}<0.01$

* significant at $\mathrm{p}<0.05$

$\dagger$ significant at $\mathrm{p}<0.1$ 
All three hypotheses related to service quality dimensions and service satisfaction $\left(\mathrm{H}_{2 \mathrm{a}}, \mathrm{H}_{2 \mathrm{~b}}\right.$ and $\left.\mathrm{H}_{2 \mathrm{c}}\right)$ are supported $(\beta=0.111$, $\mathrm{p}<0.05, \beta=0.112, \mathrm{p}<0.1$ and $\beta=0.515$, $\mathrm{p}<0.001$ respectively). In addition, service satisfaction is positively related to service loyalty. Thus, $H_{3}(\beta=0.222, \mathrm{p}<0.001)$ is accepted. These findings are in accordance with the EDT which suggests that product/ service performance positively affects consumers' satisfaction states which ultimately leads to customer retention.

Evidence shows that service switching costs are positively related to service loyalty which supports $H_{5}(\beta=0.094, \mathrm{p}<0.05)$. Table 11 also shows that service satisfaction is positively and significantly related to service loyalty $(\beta=0.222, \mathrm{p}>0.01)$, which provides support for $H_{3}$. Consumer innovativeness is not significantly related to service loyalty. Hence, $H_{6}$ is rejected $(\beta=-0.038$, $\mathrm{p}=0.343)$. For the present study, the plausible explanation for not having a significant effect between consumer innovativeness and service loyalty can be due to the existence of the switching costs. In support of this view, in the Korean mobile phone market, Kim and Yoon (2004) found spuriously loyal consumers who were not willing to defect just because of the switching costs.

As expected, hypothesis 7 is supported by the data which indicates that consumers' innovativeness significantly and negatively affects the consumers' service satisfaction $(\beta=-0.161, \mathrm{p}<0.01)$. This finding is in line with the theory of exploratory buyer behaviour. It is understood that the consumers with a high exploratory component tend to be dissatisfied since it is embedded in their characters to explore more and to seek for newness.
In testing the mediation effect of service satisfaction, the results reveal that service satisfaction partially mediates the relationship between 'technical quality and service loyalty' (Table 8) and 'functional quality and service loyalty', (Table 9). On the other hand, service satisfaction fully mediates the relationship between ' $C R C$ and service loyalty'. (Table 10) Thus, $H_{4 d}, H_{4 b}, H_{4 c}$ are supported.

\section{Conclusion, Limitations and Future Research Directions}

The objective of this study was to shed some light on the service loyalty issue in the Malaysian mobile phone service industry. The study's results found that for enhancing service loyalty, service satisfaction plays the most influential role, followed by technical quality, functional quality, and service switching costs. However, consumer innovativeness does not affect service loyalty. Moreover, satisfaction mediates the relationship between service quality and service loyalty.

This study contributed significantly to the present theory and practices. Theoretically this is a pioneer study that examined the influence of consumer innovativeness on service satisfaction, loyalty and switching behaviour. Furthermore, this study examined the direct and indirect relationships between the variables, in a new research context. This is likely to enhance the knowledge related to customers' satisfaction, switching behaviour, and service loyalty in non-western cultures like Malaysia. Practically, this study contributes to the issue of service switching in the mobile phone service industry which, by its nature, deals with contractual, voluntary and longterm relationship characteristics. Furthermore, other communication-related service opera- 
tors (e.g., Internet, e-mail) can also benefit from the present study's findings. This research comprises the important work of examining the service switching costs effect on service loyalty/switching under the MNP policy, along with the presence of other contributing factors in mobile phone service usage.

These findings provide an important basis for practitioners in formulating their service quality, service satisfaction, and service switching cost building strategies to minimize switching behaviour, as they will lead to better user retention. It was expected that the higher the level of service switching costs, the greater would be the likelihood that service satisfaction would lead to greater service loyalty/lower service switching. It is evident that it influences service loyalty directly. This finding implies that service satisfaction/dissatisfaction poses a stronger effect on service loyalty/switching rather than service switching costs. Moreover, while MNP has lessened the switching barrier effect, it does not eliminate it altogether. Hence, the service providers in a mature market, like the mobile phone service usage one, should develop strong service switching costs related to 'adaptation costs' and 'benefit loss costs' as well as other service switching costs (e.g., customer lock-in and creating high economic costs involved in switching to a new service provider, etc.) as the switching barrier to retain their users as a short term retention strategy. Consequently, it will help to support the breadth strategy. Furthermore, it is evident that service satisfaction is very crucial to building service loyalty. Thus, developing customer reward programs that concretely compensate customers, such as mileage programs and price discounts, in order to increase service satisfaction as well as loss costs, can be another important strategy to consider. It is also important to emphasize improving proper service quality elements to ensure long term loyalty, to maintain the growth of the industry (breadth strategy) as well as to contribute to the depth of usage. In this regard, service providers need to focus more on the technical, as well as the functional dimensions (as these two dimensions influence service loyalty both directly and indirectly) rather than customer relationship competencies to enhance service loyalty.

Although this research has provided relevant and interesting insights into the understanding of service loyalty and service switching, it is important to recognize some limitations associated with this study. Overcoming these limitations will open new avenues for future research. The analysis of this study relies on cross-sectional data. Thus, to provide a more accurate causal interpretation of the relationship among the study variables, additional future research can be longitudinal in nature, in which exogenous factors are captured (e.g., satisfaction, perceived service quality, service switching cost, consumer innovativeness) before data on endogenous criteria are collected (e.g., loyalty and switching). Moreover, the present study's scope is confined to the mobile phone service industry only, and therefore, replication of this study on a wider scale with different industries is essential for testing the greater generalization/applicability of the findings to contribute to the empirical literature. For example, future studies can examine the effects of service switching costs, service satisfaction, service quality and consumer innovativeness involving service encounters that require greater and closer interactions and exchanges among network players (including consumers and service providers), such as health care services, education, hospitality/ travel services and financial services. 


\section{References}

Khatibi, A. A., H. Ismail, and V. Thyagarajan. 2002. What drives customer loyalty: An analysis from the telecommunications industry. Journal of Targeting, Measurement and Analysis for Marketing 11(1): 34-44.

Adham, K. A., and M. F. Said. 2011. DiGi.com: Strategies for capturing market share. Asian Journal of Case Research 4 (1): 19-56.

Ahn, J., S. Han, and Y. Lee. 2006. Customer churn analysis: Chun determinants and mediation effects of partial defection in the Korean mobile telecommunications service industry. Telecommunications Policy 30: 552-568.

Al-Kwifi, S., U. Zafar, and A. D. Yammout. 2014. Brand switching of high-technology capital products: How product features dictate the switching decision. Journal of Product and Brand Management 23 (4/ 5): 322-332.

Anderson, R. E., and S. S. Srinivasan. 2003. E-satisfaction and e-loyalty: A contingency framework. Psychology and Marketing 20 (2): 123-138.

Anderson, E.W., C. Fornell, and D. R. Lehmann. 1994. Customer satisfaction, market share and profitability: Findings from Sweden. Journal of Marketing 58: 129-41.

Annala , S., S. Viljainen, and J. Tuunanen. 3013. Rationality of supplier switching in retail electricity markets. International Journal of Energy Sector Management 7 (4): 459 - 477.

Arbuckle, J. L., and W. Wothke. 1999. AMOS 4.0 User's Guide. Chicago: Smallwaters Corp.

Athanassopoulos, A. D. 1997. Another look into the agenda of customer satisfaction. International Journal of Bank Marketing 15 (7): 264-278.

Aydin, S., and G. Ozer. 2005. National customer satisfaction indices: An implementation in the Turkish mobile telephone market. Marketing Intelligence and Planning 23 (5): 486-504.

Aydin, S., G. Ozer, and O. Arasil. 2005. Customer loyalty and the effect of switching costs as a moderator variable. Marketing Intelligence and Planning 23 (1): 89-103.

Babakus, E., and G. W. Boller. 1992. An empirical assessment of the SERVQUAL scale: Journal of Business Research 24: 253-68.

Bagozzi, R. P., and L. W. Phillips. 1982. Representing and testing organizational theories. A holistic construal. Administrative Science Quarterly 27: 459-489.

Bagozzi, R. P., and Y. Yi. 1988. On the evaluation of structural equation models. Journal of the Academy of Marketing Science 16 (1): 74-94.

Ball, D., P. S. Coelho, and M. J. Vilares. 2006. Service personalization and loyalty. Journal of Services Marketing 20(6): 391-403.

Bandalos, D. L. and S. J. Finney. 2001. Item parceling issues in structural equation modeling. In G. A. Marcoulides and R. E. Schumacker (Eds.), New Developments and Techniques in Structural Equation Modeling (pp. 269-296). Mahwah, NJ: Law rence Erlbaum Associates, Inc.

Baumgartner, H., and J. B. E. M. Steenkamp. 1996. Exploratory consumer buying behaviour: Conceptualization and measurement. International Journal of Research in Marketing 13: 121-137.

Beggs, A. and P. Klemperer. 1992. Multi-period competition with switching costs. Econometrica 60(3): 651666.

Bennett, J. A. 2000. Mediator and moderator variables in nursing research: conceptual and statistical differences. Research in Nursing and Health 23: 415-420. 
Berlyne, D. E. 1960. Conflict, Arousal and Curiosity. New York: McGraw Hill Book Company, Inc.

Berlyne, D. E. 1963. Motivational problems raised by exploratory and epistemic behaviour. In S. Koch (Eds.), Psychology: A Study of Science 5: 284-364, New York: McGraw-Hill.

Berlyne, D. E. 1978. Curiosity and learning. Motivation and Emotion 2: 97-175.

Bharadwaj, S. G., P. R. Vanradarajan, and J. Fahy. 1993. Sustainable competitive advantage in services industries: A conceptual model and research proposal. Journal of Marketing 57: 83-99.

Bitner, M. J., and A. R. Hubbert. 1994. Encounter satisfaction versus overall satisfaction versus quality. In R. T. Rust and R. L. Oliver (Eds.), Service Quality: New Directions in Theory and Practice (pp. 72-94). Thousand Oaks, CA: Sage.

Bodet, G. 2008. Customer satisfaction and loyalty in service: Two concepts, four constructs, several relationships. Journal of Retailing and Consumer Services 15: 156-162.

Boulding, W., A. Kalra, R. Staelin, and V. A. Zeithaml. 1993. A dynamic process model of service quality: from expectations to behavioural intentions. Journal of Marketing Research 30(February): 7-27.

Brady, M. K., and Robertson, C. J. 2001. Searching for a consensus on the antecedent role of service quality and satisfaction: Exploratory cross-national study. Journal of Business Research 51: 53-60.

Bristow, D. N., and Sebastian, R. J. 2001. Holy cow! Wait'til next year! A closer look at the brand loyalty of Chicago Cubs baseball fans. Journal of Consumer Marketing 18(3): 256-275.

Burnham, T. A., J. K. Frels, and V. Mahajan. 2003. Consumer switching costs: A typology, antecedents, and consequences. Journal of the Academy of Marketing Science 31 (2): 109-126.

Byrne, B. M. 2010. Structural Equation Modeling with AMOS: Basic Concepts, Application, and Programming (2 ${ }^{\text {nd }}$ Eds.). Ney York: Routledge.

Caruana, A. 2002. Service loyalty: The effects of service quality and the mediating role of customer satisfaction. European Journal of Marketing 36 (7/8): 811-828.

Cattell, R. B. and C. A. Burdsal Jr. 1975. The radial parceling double factoring design: Solution to the itemvs.-parcel controversy. Multivariate Behavioral Research 10:165-179.

Chea, S., and M. M. Luo. 2005. E-service customer retention: The roles of negative affectivity and perceived switching costs. Proceeding of the Eleventh America Conference on Information System. Omaha, NE, USA.

Chenet, P., C. Tynan, and A. Money. 1999. Service performance gap: re-evaluation and redevelopment. Journal of Business Research 46(2): 133-47.

Churchill, H. 1942. How to measure brand loyalty. Advertising and Selling, 35(24): 11-16.

Churchill, G.A. Jr. 1979. A paradigm for developing better measures of marketing 'constructs. Journal of Marketing Research 16: 64-73.

Clark, T. 1990. International marketing and national character: a review and proposal for an integrative theory. Journal of Marketing 54 (4): 66-79.

Cody, K. and B. Hope. 1999. EX-SERVQUAL: an instrument to measure service quality of extranets. Proceedings of the 10th Australasian Conference on Information Systems. Wellington.

Cortina, J. M. 1993. What is coefficient alpha? An examination of theory and applications. Journal of Applied Psychology 78(1): 98-104.

Cowart, K. O., G. L. Fox, and A. E. Wilson. 2008. A structural look at consumer innovativeness and selfcongruence in new product purchases. Psychology and Marketing 25(12): 1111-1130. 
Coyles, S., and T. C. Gokey. 2005. Customer retention is not enough. Journal of Consumer Marketing 22 (2): 101-105.

Cronin, J. J. and S. A. Taylor. 1992. Measuring service quality: A reexamination and extension. Journal of Marketing 56 (2): 55-68.

Daneels, E., and E. J. Kleinsmith. 2001. Product innovativeness from the firm's perspective: its dimensions and their relation with project selection and performance. Jour nal of Product Innovation and Management 18(6): 357- 73.

Davis-Sramek, B., C. Droge, J. T. Mentzer, and M. B. Myers. 2009. Creating commitment and loyalty behaviour among retailers: What are the roles of service quality and satisfaction? Journal of the Academy of Marketing Science 37 (4): 440-454.

Dean, A. M. 2002. Service quality in call centers: Implications for customer loyalty. Managing Service Quality 12 (6): 414-423.

deRuyter, K., W. Martin, and J. Bloemer. 1998. On the relationship between perceived service quality, service loyalty and switching costs. International Journal of Service Industry Management 9: 436-453.

Diamantopoulos, A. and B. B. Schlegelmilch. 1997. Taking the Fear Out of Data Analysis. London: Dryden.

Donnelly Jr., J. H., and J. M. Ivancevich. 1974. A methodology for identifying innovator characteristics of new brand purchasers. Journal of Marketing Research 11 (August): 331-334.

Dubé, J. P., G. J. Hitsch, and P. E. Rossi. 2009 Do switching costs make markets less competitive? Journal of Marketing Research 46 (August): 435-445.

Engel, J. R, R. J. Kegerreis, and R. D. Blackwell. 1969. Word-of-mouth communication by the innovator. Journal of Marketing 33 (July): 15-19.

Ennew, C. T., and M. R. Binks. 1999. Impact of participative service relationships on quality, satisfaction, and retention: An exploratory study. Journal of Business Research 46 (2): 121-32.

Eshghi, A., S. K. Roy, and S. Ganguli. 2008 Service quality and customer satisfaction: An empirical investigation in the Indian mobile telecommunication services. The Marketing Management Journal 18 (2): $119-144$.

Fornell, C. 1992. A national customer satisfaction barometer: Swedish experience. Journal of Marketing 56 (1): $6-21$.

Fornell, C, M. D. Johnson, E. W. Anderson, J. Cha, and B. E. Bryant. 1996. The American customer satisfaction index: Nature, purpose and findings. Journal of Marketing 60: 7-18.

Fowler, K., and E. Bridges. 2010. Consumer innovativeness: Impact on expectations, perceptions, and choice among retail formats. Journal of Retailing and Consumer Services, 17: 492-500.

Ganesh, J., M. J. Arnold, and K. E. Reynolds. 2000. Understanding the customer base of service providers: An examination of the differences between stayers and switchers. Journal of Marketing 64 (3): 687.

Garver, M. S., and J. T. Mentzer. 1999. Logistics research methods: Employing structural equation modeling to test for construct validity. Journal of Business Logistics 20 (1): 33-57.

Garvin, D. A. 1983. Quality on the line. Harvard Business Review 61 (September-October): 65-73.

Giese, J. L., and J. A. Cote. 2000. Defining customer satisfaction. Academy of Marketing Science Review. http:/ /www.ansreview.org/articles/giese 01-2000.pdf [11 July 2014]. 
Goldsmith, R. E., F. d'Hauteville, and L. R. Flynn. 1998. Theory and measurement of consumer innovativeness: A transnational evaluation. European Journal of Marketing 32 (3/4): 340-353.

Greenhalgh, T., G. Robert, P. Bate, F. McFarlane, and O. Kyriakidou. Diffusion of Innovations in Service Organizations: A Systematic Review. Massachussetts: Blackwell Publishing.

Greenwald, A. G., and A. R. Pratkanis 1988. On the use of "theory" and the usefulness of theory. Psychological Revien 95: 575-579.

Gremler, D. D., and S. W. Brown. 1996 Service loyalty: Its nature, importance, and implications. In Edvardsson, B., S. W. Brown, R. Johnston, and E. E. Scheuing (Eds),Proceedings of American Marketing Association: 171-180.

Gronroos, C. 1984. A service quality model and its marketing implications. European Journal of Marketing 18 (4): $36-44$.

Guest, L. 1942. The genesis of brand awareness. Journal of Applied Psychology 26: 800-808.

Guest, L. 1944. A study of brand loyalty. Journal of Applied Psychology 28: 16-27.

Gustafsson, A., M. D. Johnson, and I. Roos. 2005. The effects of customer satisfaction, relationship commitment dimensions, and triggers on customer retention. Journal of Marketing, 69: 210-218.

Habib, F.Q., A. H. Salleh, and N. L. Abdullah. 2011. Service switching behavior among mobile phone users. Proceedings of $2^{n d}$ International Research Symposium in Service Management: Service Imperatives in the New Economy (IRSSM-2): 136-144.

Hair, J. F. Jr., W. C. Black, B. J. Babin, R. E. Anderson, and R. L. Tatham. 2006. Multivariate Data Analysis (6 $6^{\text {th }}$ eds.). Upper Saddle River, New Jersey, USA: Prentice - Hall, International Inc.

Haque, A., A. Khatibi, A. Raquib, and S. Al Mahmud. 2007. Consumer perception and its choice of mobile telecom service provider in Malaysia. Journal of International Business and Economics 7 (2). http:// goliath.ecnext.com/coms2/gi_0198- 475321/Consumer-perception-and-its-choice.html [21 May 2009].

Harris, L. C., and M. M. H. Goode. 2004. The four levels of loyalty and the pivotal role of trust: A study of online service dynamics. Journal of Retailing 80: 139-158.

Hauser, J. R. and B. Wernerfelt. 1990. An evaluation cost model of consideration sets Journal of Consumer Research 16: 393-408.

Heskett, J. L. 2002. Beyond customer loyalty. Managing Service Quality 12 (6): 355-357.

Hirschman, E. C. 1980. Innovativeness, novelty seeking, and consumer creativity. Journal of Consumer Research 7 (December): 283-295.

Hirschman, E. C. 1984. Experience seeking: A subjectivist perspective of consumption. Journal of Business Research 12 (1): 115-136.

Hirunyawipad, T., and A. K. Paswan. 2006. Consumer innovativeness and perceived risk: Implications for high technology product adoption. Journal of Consumer Marketing 23 (4): 182-198.

Hoffmann, S., and K. Soyez. 2010. A cognitive model to predict domain-specific consumer innovativeness. Journal of Business Research 63: 778-785.

Holmbeck, G. N. 1997. Toward terminological, conceptual, and statistical clarity in the study of mediators and moderators: Examples from the child-clinical and pediatric psychology literature. Journal of Consulting and Clinical Psychology 4: 599-610. 
International Data Corporation (IDC) Report. 2007. Malaysia Mobile Services Customer Churn and Loyalty Survey. http:// www.reportbuyer.com/telecoms/mobile_markets/malaysia_mobile_ services_customer_churn_loyalty_survey_2007.html [7 July 2009].

Ismail, I., H. Haron, D. N. Ibrahim, and S. Mohd. Isa. 2006. Service quality, client satisfaction and loyalty towards audit firms. Perceptions of Malaysian public listed companies. Managerial Auditing Journal 21 (7): 738-756.

Izogo, E.E., and I. E. Ogba. 2015. Service quality, customer satisfaction and loyalty in the automobile repair services sector. International Journal of Quality and Reliability Management 32 (3): 250 - 269.

Johnson, M. D., A. Gustafsson, T. W. Andreassen, L. Lervik, and J. Cha. 2001. The evolution and future of national customer satisfaction index models. Journal of Economic Psychology 22: 217-245.

Johnson, W. C., and A. Sirikit. 2002. Service quality in the Thai telecommunications industry: A tool for achieving a sustainable competitive advantage. Management Decision 40 (7): 693-701.

Jones, T., and Taylor, S. F. 2007. The conceptual domain of service loyalty: How many dimensions. Journal of Services Marketing 21 (1): 36-51.

Jöreskog, K. G. 1971. Statistical analysis of sets of congeneric tests. Psychometrika 36: 109-133.

Jayanti, R. and A. Jackson. 1991. Service satisfaction: an exploratory investigation of three models. $A d-$ vances in Consumer Research 18: 603-610.

Karakaya, F., and M. J. Stahl. 1989. Barriers to entry and market entry decisions in consumer and industrial goods markets. Journal of Marketing 53 (April): 80-91.

Keiningham, T. L., T. G. Vavra, L. Aksoy, and H. H. Wallard. 2005. Loyalty Myths: Hyped Strategies that Will Put You Out of Business - And Proven Tactics that Really Work. Wiley.

Kim, J. S., J. Kaye, and L. K. Wright. 2001. Moderating and mediating effects in causal models. Issues in Mental Health Nursing 22: 63-75.

Kim, H. S., and C. H. Yoon. 2004. Determinants of subscriber churn and customer loyalty in the Korean mobile telephony market. Telecommunications Policy 28: 751-765.

Kim, M., Park, M., and Jeong, D. (2004). The effects of customer satisfaction and switching barrier on customer loyalty in the Korean mobile telecommunication services. Telecommunications Policy, 28(2), $145-159$.

Klemperer, P. (1995). Competition when consumers have switching costs: An overview with applications to industrial organization, macroeconomics and internatio nal trade. Review of Economic Studies 62: 515-39.

Kline, R. B. 2005. Principles and practice of Structural Equations Modeling (2nd Eds.). New York: Guilford Press.

Kuhn, T. S. 1962. The Structure of Scientific Revolutions. 3rd ed. Chicago, IL: University of Chicago Press.

Kumar, A., and H. Lim. 2008. Age differences in mobile service perceptions: Comparison of Generation $\mathrm{Y}$ and baby boomers. Journal of services marketing 22 (7): 568-577.

Lai, F. L., M. Griffin, and B. J. Babin. 2009. How quality, value, image, and satisfaction create loyalty at a Chinese telecom. Journal of Business Research 62: 980-986.

LaTour, S. A. and N. C. Peat. 1979. Conceptual and methodological issues in consumer satisfaction research. Advances in Consumer Research 6: 431-37. 
Leavitt, C. 1976. Consumer satisfaction as the ultimate life force. Advances in Consumer Research 3 (1): 252 258.

Lee, J., Y. Kim, J. D. Lee, and Y. Park. 2006. Estimating the extent of potential competition in the Korean mobile telecommunications market: Switching costs and number portability. International Journal of Industrial Organization, 24: 107- 124.

Leisen, B., and C. Vance. 2001. Cross-national assessment of service quality in the telecommunication industry: Evidence from the USA and Germany. Managing Service Quality 11 (5): 307-317.

Lin, A., and C. Chou. 2004. Antecedents and consequences of customer switching costs for the mobile phone market.http://wwwsoc.nii.ac.jp/jepa/IC2004/paper/44\%20Chou.pdf [28 December 2008].

Liu, M., I. A. Wong, R. Chu , G. J. Shi, J. L. Brock, and T. S. M. Tseng. 2014. Can a socially responsible casino better retain its management staff? From an internal customer perspective. Asia Pacific Journal of Marketing and Logistics 26(4): 520-539.

Little, T. D., W. A. Cunningham, G. Shahar, and K. F. Widaman. 2002. To parcel or not to parcel: Exploring the question, weighing the merits. Structural Equation Modeling 9 (2): 151-173.

Lopez, J. P. M., Y. P. Redondo, and F. J. S. Olivan. 2006. The impact of customer relationship characteristics on customer switching behavior, differences between switchers and stayers. Managing Service Quality, 16(6): 556-574.

Malaysian Communications and Multimedia Commission (MCMC). 2005. Hand phone user surveys: Statistical brief number three. Cyberjaya. Selangor.

Malaysian Communications and Multimedia Commission (MCMC). 2006. Hand phone user surveys: Statistical brief number four. Cyberjaya. Selangor:.

Malaysian Communications and Multimedia Commission (MCMC). 2009. Hand phone user surveys: Statistical brief number nine. Cyberjaya. Selangor.

Mittelstaedt, R. A., S. L. Grossbart, W. W. Curtis, and S. P. Devere. 1976. Optimum stimulation level and the adoption decision process. Journal of Consumer Research 3: 84-94.

Mavri, M., and G. Ioannou. 2008. Customer switching behavior in Greek banking services using survival analysis. Managerial Finance 34 (3): 186-197.

McAlister, L., and E. Pessemier. 1982. Variety seeking behavior: An interdisciplinary review. Journal of Consumer Research 9: 311-322.

Midgley, D. F. 1977. Innovation and New Product Marketing. New York: Halsted Press

Midgley, D. F., and G. R. Dowling. 1978. Innovativeness: The concept and its measurement. Journal of Consumer Research 4 (March): 229-242.

Mittal, B., and W. M. Lasser, W. M. 1998. Why do customers switch? The dynamics of satisfaction ersus loyalty. The Journal of Service Marketing 12 (3): 177-194.

Yaacob, M. R. N. R. Nik Ismail, and N. S. Ismail. 2010. An Investigation of the determinants of customers' loyalty of the Maxis Communications Berhad. Proceedings of International Conference on Business and Economic Research - ICBER 2010. Hilton Hotel, Kuching, Sarawak, Malaysia. h t t p : / / www.internationalconference.com.my/proceeding/icber2010_proceeding PAPER_271_DeterminantsOfCustomersLoyalty.pdf [5 November 2010].

Narayana, M. R. 2011. Telecommunications services and economic growth: Evidence from India. Telecommunications Policy 35 (2): 115-127. 
Oliver, R. L. 1977. Effect of expectation and disconfirmation on post-exposure product evaluations: An alternative interpretation. Journal of Applied Psychology 62 (April): $\quad 480-486$.

Oliver, R. L. 1980. A cognitive model for the antecedents and consequences of satisfaction. Journal of Marketing Research 17: 460-469

Oliver, R. L. 1981. Measurement and evaluation of satisfaction processes in retail settings. Journal of Retailing 57 (Fall) (25-48):138-139.

Oliver, R.L. 1997. Satisfaction: A Behavioural Perspective on the Consumer. New York, NY: The McGraw-Hill Companies.

Olsen, S. O. 2002. Comparative evaluation and the relationship between quality, satisfaction, and repurchase loyalty. Academy of Marketing Science 30 (3): 240-249.

Parasuraman, A., V. A. Zeithaml, and L. L. Berry. 1985. A conceptual model of service quality and its implications for future research. Journal of Marketing 49 (Fall): 41-50.

Parasuraman, A., V. A. Zeithaml, and L. L. Berry. 1988. SERVQUAL: A multiple item scale for measuring consumer perceptions of service quality. Journal of retailing 64: 12-40.

Patterson, P. G. 1993. Expectations and product performance as determinants of satisfaction for a highinvolvement purchase. Psychology and Marketing 10 (5): 449-465.

Patterson, P. G., L. W. Johnson, and R. A. Spreng. 1997. Modelling the determinants of customer satisfaction for business-to-business professional services. Academy of Marketing Science 25 (1): 4-17.

Payne, J. W. 1982. Contingent decision behaviour. Psychological Bulletin 92 (2): 382-402.

Peyrot, M. 1996. Causal analysis: Theory and application. Journal of Pediatric Psychology 21: 3-24.

Porter, M. E. 1985. The Competitive Advantage: Creating and Sustaining Superior Performance. New York: Free Press.

Quoquab, F., N. M. Yasin, and R. A. Dardak, R. 2014. A qualitative inquiry of multi-brand loyalty: Some propositions and implications for mobile phone service providers. Asia Pacific Journal of Marketing and Logistics 26(2): 250-271

Raju, P. S. 1980. Optimum stimulation level: Its relationship to personality, demographics, and exploratory behavior. Journal of Consumer Research 7: 272-282.

Raju, P. S. and M. Venkatesan. 1980. Exploratory behavior in the consumer context: A state of the art review. Advances in Consumer Research 7: 258-263.

Reichheld, F. F. 1996. Learning from customer defections. Harvard Business Revien 74(2): 56-59.

Reichheld, F. 2002. The one number you need. Harvard Business Review 81 (12): 46-55.

Reichheld, F. F., and W. E. Sasser. 1990. Zero defections: Quality comes to services Harvard Business Revien 68: 105-111.

Robertson, T. 1968. Purchase sequence response: innovators vs. non-innovators. Journal of Advertising Research 8 (March): 47-52.

Rust, R. T. and A. J. Zahorik. 1993. Customer satisfaction, customer retention and market share. Journal of Retailing 69:193-215.

Said, M. F., and K. A. Adham. 2010. Online mobile content innovations and industry structure: Implications for firms' strategies. International Journal of Economics and Management 4 (1): 101-119

Salegna, G. J., and S. A. Goodwin. 2005. Consumer loyalty to service providers: An integrated conceptual model. Journal of Consumer Satisfaction, Dissatisfaction and Complaining Behaviour 18: 51-67. 
Schultz, D. E. 2005. The loyalty paradox: What is brand loyalty after all? Marketing Management 14 (5): $10-$ 11.

Seo, D., C. Ranganathan, and Y. Babad. 2008. Two-level model of customer retention in the US mobile telecommunications service market. Telecommunications Policy 32: 182-196.

Shin, D. H., and W. Y. Kim. 2008. Forecasting customer switching intentions in mobile service: An exploratory study of predictive factors in mobile number portability. Technical Forecasting and Social Change 75: $854-874$.

Spreng, R. A., S. B. MacKenzie, and R. W. Olshavsky. 1996. A re-examination of the determinants of consumer satisfaction. Journal of Marketing 60 (July): 15-32.

Sudhahar, J. C., D. Israel, A. P. Britto, and M. Selvam. 2006. Service loyalty measurement scale: A reliability assessment. American Journal of Applied Sciences 3 (4): 1814-1818.

Tabachnick, B. G., and L. S. Fidell. 1989. Using multivariate statistics (2 ${ }^{\text {nd }}$ ed.). New York: Harper and Row Publishers.

Taylor, J. W. 1977. A striking characteristic of innovators. Journal of Marketing Research 14 (February): 104107.

Turel, A., and A. Serenko. 2006. Satisfaction with mobile services in Canada: An empirical investigation. Telecommunications Policy 30: 314-331.

Turkyýlmaz, A., and C. Ozkan. 2007. Development of a customer satisfaction index model: an application to the Turkish mobile phone sector. Industrial Management and Data Systems 107 (5): 672-687.

Tuu, H. H., and S. O. Olsen. 2013. Consideration set size, variety seeking and the satisfaction repurchase loyalty relationship at a product category level. Asia Pacific Journal of Marketing and Logistics 25 (4): 590-613.

Ueltschy, L. C., M. Laroche, A. Eggert, and U. Bindl. 2007. Service quality and satisfaction: an international comparison of professional services perceptions. Journal of Services Marketing 21 (6): 410 423.

Wang, Y., and H. P. Lo. 2002. Service quality, customer satisfaction and behavior intentions: Evidence from China's telecommunication industry. Info-The Journal of Policy, Regulation and Strategy for Telecommunications 4 (6): 50-60.

Wang, H. C., J. G. Pallisterb, and G. R. Foxall. 2006. Innovativeness and involvement as determinants of website loyalty: a test of the style/involvement model in the context of internet buying. Technovation 26: $1357-1365$.

Weiss, A. M., and J. B. Heide.1993 . The nature of search in high-technology markets Journal of Marketing Research 30 (May): 220-233.

Woodruff, R. 1997. Customer value: the next source for competitive advantage. Journal of Academy of Marketing Science 25 (Spring): 139-153.

Woratschek, H., and C. Horbel. 2003. Variety seeking behavior and recommendations: Empirical findings and consequences for the management of the service profit chain. In D. Turley and S. Brown (Eds.), European Advances in Consumer Research “All Changed, Changed Utterly?” 6: 82-87. Valdosta, GA: Association for Consumer Research.

Xie, Y. H. 2008. Consumer innovativeness and consumer acceptance of brand extensions. Journal of Product and Brand Management 17 (4): 235-243. 
Yang, Z., and R. T. Peterson. 2004. Customer perceived value, satisfaction, and loyalty: The role of switching costs. Psychology and Marketing 21 (10) (October): 799-822.

Zeithaml, V. A. 1988. Consumer perceptions of price, quality, and value: A means-end and synthesis of evidence. Journal of Marketing 52 (3): 2-22.

Zeithaml, V. A. 2000. Service quality, profitability and economic worth of customers: What we know and what we need to learn. Journal of the Academy of Marketing Science 28 (1): 67-85.

Zeithaml, V. A. and M. J. Bitner. 1996. Services Marketing. New York: McGraw-Hill.

Zeithaml, V. A. and M. J. Bitner. 2000. Services Marketing: Integrating Customer Focus Across the Firm (2 $2^{\text {nd }}$ eds.). New York, NY: McGraw Hill.

Zeithaml, V. A., L. L. Berry, and A. Parasuraman. 1988. Communication and control processes in the delivery of service quality. Journal of Marketing 52 (2): 35-48.

Zeithaml, V. A., L. L. Berry, and A. Parasuraman. 1996. The behavioral consequences of service quality. Journal of Marketing 60 (April): 31-46. 
